\title{
Statehood Experience, Legal \\ Traditions, and Climate Change Policies
}

James B. Ang and Per G. Fredriksson 2016

EGC Report No: 2016/10

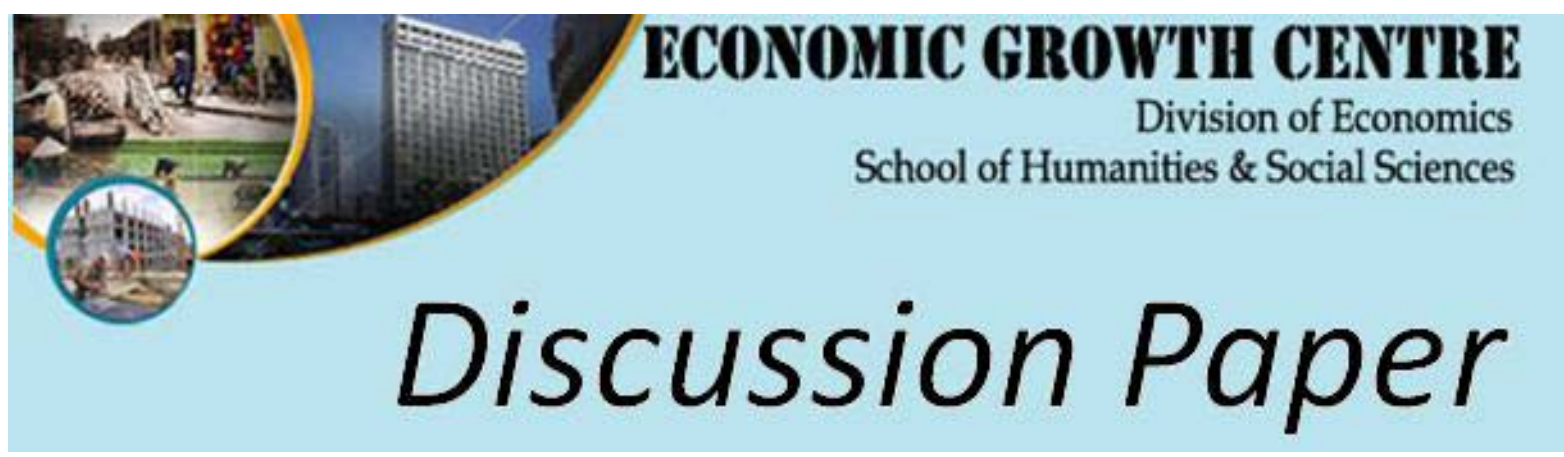


The author(s) bear sole responsibility for this paper.

Views expressed in this paper are those of the author(s) and not necessarily those of the Economic Growth Centre, NTU. 


\title{
Statehood Experience, Legal Traditions and Climate Change Policies*
}

\author{
James B. Ang ${ }^{\dagger} \quad$ Per G. Fredriksson ${ }^{\ddagger}$
}

\begin{abstract}
This paper investigates how the implementation of modern climate change policies is related to former colonies' length of state history and their legal heritage. We argue that countries with longer statehood experience around the time of colonization were better equipped to implement the legal philosophies transplanted by their colonial powers. Therefore, the implications of receiving British common law versus French civil law should be particularly important in countries with a greater accumulated history of statehood. Using a cross section of up to 78 former colonies, our results provide support for this hypothesis. In particular, our estimates demonstrate that common law countries have weaker modern climate change policies than civil law countries and the difference is inflated by a longer statehood experience, measured by the length of state history from 1-1800 AD. Legal origin has no effect in areas which, by the time of colonization, had no statehood experience.
\end{abstract}

Key words: Environmental policy; climate change; state antiquity; history; state capacity; legal origins; colonization.

JEL classification: Q58; K23; O44

\footnotetext{
${ }^{*}$ The authors are grateful for helpful comments on this paper from Roger von Haefen, Kathryn Perry and seminar participants at Florida Gulf Coast University. The usual disclaimers apply.

${ }^{\dagger}$ Corresponding author. Department of Economics, School of Humanities \& Social Sciences, Nanyang Technological University, 14 Nanyang Drive, Singapore 637332.E-mail: James.Ang@ntu.edu.sg.

${ }^{\ddagger}$ Department of Economics, University of Louisville, Louisville, KY 40292, USA. E-mail: per.fredriksson@louisville.edu.
} 


\section{Introduction}

Climate change has severe impacts on developing countries, affecting physical systems (rivers, lakes, floods, droughts, coastal erosion, sea level effects), biological systems (terrestrial and marine ecosystems), and human systems (health and livelihoods, food production) (IPCC, 2014). The literature explaining the pattern of policies addressing climate change and other environmental problems tends to emphasize relatively modern determinants, including the current levels of corruption, democracy, recent political instability, various political institutions, and trade policy. ${ }^{1}$ However, history should not be ignored when we attempt to understand present-day policymaking. Is it possible that history going as far back as 1 AD still matters significantly for today's environmental policy outcomes? In this paper, we study the joint effect of long-term statehood experience and legal heritage on climate change policy outcomes in former colonies. To the best of our knowledge, this is the first paper to merge these two strands of the literature. Moreover, it is the first to investigate the role of statehood history or state capacity for any type of environmental policymaking.

Long-term historical processes, including the development of agriculture, urbanization, the use of money as a medium of exchange, taxation, and experience with government administration all build stocks of human capital and experience through learning-by-doing (Burkett et al., 1999; Putterman, 2000; Acemoglu et al., 2015). ${ }^{2}$ The level of accumulation of statehood experience influences a country's ability to consolidate and centralize power, creates a capable bureaucracy which provides overall "state capacity" (Gennaioli and Rainer, 2007; Besley and Persson, 2009, 2011; Besley et al., 2013; Michalopoulos and Papaioannou, 2014). Besley and Persson (2011) present a theory predicting that state (fiscal) capacity and good institutions (legal capacity) are complements, which is supported by empirical evidence provided by Michalopoulos and Papaioannou (2014).

The form of legal system utilized has important implications for regulatory, judicial, financial, and economic outcomes; the literature has primarily focused on the implications of French civil law versus British common law for financial development and regulation (see, for example, La Porta et al., 1997, 1998, 2008; Botero et al., 2004). The resulting Legal Origins Theory (LOT) developed by La Porta et al. (2008) argues that British common law allocates more weight to private markets, the courts, and decentralized policymaking, while French civil law gives a strong role to the centralized state. Recent empirical work based on LOT finds that common law countries set weaker climate change policies than civil law countries (Fredriksson and Wollscheid, 2015).

So far, the literature on statehood experience has developed parallel to the literature on legal origins. We remedy this gap in the literature. We argue that the implications of receiving common law versus civil law should be particularly important in countries with a greater accumulated history of statehood at the time of colonization. In those countries, state (administrative) capacity was further developed, political power tended to be more centralized, the preexisting accountability of

\footnotetext{
${ }^{1}$ See, for example, Congleton (1992), Damania et al. (2003), Fredriksson and Svensson (2003), Barbier et al. (2005), Farzin and Bond (2006), List and Sturm (2006), Hotte and Winer (2012), and Oliva (2015).

${ }^{2}$ The literature on the very long run determinants of economic development include, for example, Kremer (1993), Galor and Weil (2000), Comin et al. (2010) and Putterman and Weil (2010).
} 
local leaders was greater, and the ability to receive and implement the transplanted legal framework from the colonizer was therefore enhanced. In contrast, areas without much statehood experience did not have a strong bureaucracy or state capacity, and the transfer of the colonizer's legal approach was less complete. Our hypothesis is consequently that a longer history of statehood at the time of colonization serves to increase the differential impact of common and civil law legal origins on the stringency of modern climate change policies, as well as other environmental policies.

Using a cross section of up to 78 former colonies, our results lend support to this hypothesis. Our estimates suggest that the difference between common law and civil law countries in modern climate change policies is conditional on statehood experience, measured by the length of state history from 1-1800 AD. In particular, the divergence in modern climate change policy stringency due to legal origin (common law vs. civil law) is inflated by the length of statehood experience. Moreover, legal origin has no effect in countries which, at or around the time of colonization, had no statehood experience. We believe these are novel findings in the literature. Moreover, our findings apply more generally to several other measures of environmental policy outcomes.

These findings give a more fine-tuned picture of the role of legal origin compared to the previous literature on regulation in previous colonies. Our analysis helps improve our understanding of the long-term determinants of climate change policies and other environmental policies, as well as regulatory outcomes in general. Our result suggests that it is important to take the accumulated statehood experience into account when discussing the role of legal origin. The analysis may facilitate the prediction of which countries will tend to become leaders and laggards in the climate change policy formation process. An improved understanding of the institutional barriers created by legal and state history may also improve capacity building efforts, as well as the formulation of mechanisms and designs within international climate change treaties. Resources transfers may more easily be targeted towards their most productive uses.

The paper proceeds as follows. The next section reviews some of the related literature. Section 3 provides a discussion on the empirical specification, estimation issues and data. The empirical estimates are presented and analysed in Section 4. Several robustness checks are also performed, including the use of an alternative dependent variable. The last section summarizes and concludes.

\section{Related Literature and Hypothesis Specification}

The state is one of the most important forms of institutional development. The creation of nation states has led to a number of fundamental and far-reaching changes in human history. In recent years, statehood experience (sometimes denoted "state antiquity" in the literature) has gained considerable attention from the literature on long-run comparative economic development, helping to uncover the reasons for low income levels (Putterman, 2008; Putterman and Weil, 2010), bad institutions (Ang, 2013b), unequal distribution of income (Putterman and Weil, 2010), and financial underdevelopment (Ang, 2013a). The results of these studies generally suggest that a longer state history is associated with more favorable economic outcomes. A longer history of statehood often 
implies a stronger state capacity in the form of legal and fiscal capabilities (Besley and Persson, 2009, 2011; Becerra et al., 2012). In particular, Michalopoulos and Papaioannou (2013) show that pre-colonial ethnic political centralization is strongly related to contemporary regional development in Africa. However, despite the above contributions, how statehood experience is related to environmental regulations has so far not been considered in the literature.

A large literature has investigated the implications of common law and civil law for modern economic and legal institutions, e.g., for the regulation of firm entry and labor; degree of judicial independence; formalism of judicial procedures; securities, company, and bankruptcy laws; and government ownership of banks (La Porta et al., 1997, 1998, 2008; Djankov et al., 2002, 2003; Botero et al., 2004). These institutions in turn have important implications for economic outcomes, e.g., unemployment and labor participation rates, corruption and the share of the unofficial economy, property rights, stock market development, and private credit. While legal systems were transplanted in a non-voluntary fashion to the colonies (David, 1985; McNeill and McNeill, 2003), legal philosophies are highly persistent even if domestic laws subsequently evolved in the recipient countries.

La Porta et al. (2008) present a Legal Origins Theory (LOT) which argues that British common law gives more weight to private markets and the courts, while civil law assigns an important role to the state. ${ }^{3}$ Botero et al. (2004) suggest that countries with different legal origins essentially employ alternative institutional technologies for the social control of business activity (see also Glaeser and Shleifer, 2002). The legacies of legal origins exhibit a high degree of institutional persistence and path dependency where historical, economic, political, social and cultural features have a lasting impact (Greif, 1998; Hodgson, 1998; Acemoglu et al., 2001; North, 2006; Marchand, 2016).

Four implications of LOT are relevant for climate change policies. First, common law favors markets and judicial resolutions, not government regulation as emphasized by civil law. ${ }^{4}$ Second, decentralized systems used in common countries are less prone to take transboundary pollution externalities into account compared to centralized systems emerging in civil law countries (see Sigman, 2014). Third, since common law respects private property relatively more, climate policies affecting capital owners are likely to be weaker in those countries. Fourth, while common law may be more adaptable to new situations as jurisprudence is more important as a source of law (Levine, 2005; Ponzetto and Fernandez, 2008), civil law country governments can more easily address emerging social problems due to a larger local bureaucracy (Mulligan and Shleifer, 2005). Overall, most of the above arguments support the hypothesis that common law should yield weaker climate change policies.

Fredriksson and Wollscheid (2015) report that former colonies with a common law legal heritage indeed set weaker climate change policies than civil law countries. Oto-Peralías and Romero-Ávila (2014) show that the effect of legal origins on several financial outcomes and business regulations

\footnotetext{
${ }^{3}$ See Klerman and Mahoney (2007) and Roe (2007) for critical views of the Legal Origins Theory (LOT) of La Porta et al. (2008).

${ }^{4}$ Botero et al. (2004) show that British common law legal origin is associated with a substantial decrease in labor regulations.
} 
is conditional on initial conditions (population density in year $1500 \mathrm{AD}$ ). In particular, the effect of common law is negatively related to pre-colonial population density, i.e. the outcome is closer to civil law countries when density is high. Berkowitz et al. (2003) argue that it does not matter significantly which form of law a country uses for it to be effective. According to them, what matters is whether the transplanted law was developed domestically, if it was received through colonization but adapted to local conditions, or whether the local population already had some familiarity with its legal principles. Under these circumstances, the demand for the law would be high and it would be used effectively to enhance economic development.

Gennaioli and Rainer (2007) discuss the importance of pre-colonial institutions in Africa, especially political centralization, for modernization programs during the colonial and the post-colonial periods. Policy coordination and implementation were facilitated by the existence of a pre-colonial hierarchy of chiefs in areas with centralized ethnic groups (see Schapera, 1970). Bargaining with senior traditional chiefs in these areas resulted in faster adoption of European policies than in areas with high political fragmentation. Preexisting accountability of local leaders in traditionally centralized systems was the mechanism which facilitated reforms. In fragmented areas, local chiefs pursued their own distorted policies, leading to lower rates of modernization and even tyranny (Tosh, 1978). Gennaioli and Rainer (2007) argue that institutions emerging in the African colonies were heavily influenced by the existing institutions found by the colonizers (see also Roberts and Mann, 1991).

Michalopoulos and Papaioannou (2013) document a strong association between African precolonial ethnic political centralization and modern regional development. Michalopoulos and Papaioannou (2013) argue that state capacity and legal capacity are complements in Africa, supporting the prediction of Besley and Persson (2011). In particular, they find that differences in national institutions (rule of law and corruption) yield differences in regional development among (Southern African) countries with high levels of state capacity. On the other hand, in (Western African) countries with low state capacity, no correlation is detected between national institutions and regional development. ${ }^{5}$ These findings indicate that differences in the adoption of a colonizer's legal system across centralized and fragmented areas should similarly be determined by the level of statehood at the time of colonization. Path dependency and institutional persistence (see, e.g., Greif, 1998; North, 2006; Marchand, 2016) have preserved or inflated the resulting differences across legal origins over time.

Our hypothesis is thus that the transfer of legal origin should be more thorough and deep-rooted with a greater impact today in countries which at the time of colonization had a longer history of statehood experience. These colonies had a more developed legal and administrative bureaucracy, and hence were in a better position to facilitate the absorption of the legal philosophies. Therefore, the difference in the stringency of climate change policies between common and civil law countries should be greater in former colonies with a more extensive statehood experience. The divergence will increase due to a longer statehood history both because the anti-regulation stance of common

\footnotetext{
${ }^{5}$ See Michalopoulos and Papaioannou (2013), Supplementary Appendix Table 16.
} 
law will be more deeply embedded, and because the pro-regulation perspective of civil law becomes more deeply rooted in the society. Our hypothesis appears novel, as the previous literature has not investigated the regulatory effects of the absorption of legal origins conditional on state history, political centralization, or and other forms of state capacity.

\section{Empirical Approach}

\subsection{Regression model}

The following model is regressed to investigate how climate change policy is related to statehood history and the legal tradition of a country:

$$
\begin{aligned}
& C C_{i}^{\text {policy }}=\alpha+\beta \text { State }_{i}+\gamma_{1} \text { CommonLawLO }_{i}+\gamma_{2} \text { MixedLawLO }_{i}+ \\
& \delta_{1} \text { State }_{i} \times \text { CommonLawLO }_{i}+\delta_{2} \text { State }_{i} \times \text { MixedLawLO }_{i}+\text { cv }_{i}^{\prime}+\varepsilon_{i}
\end{aligned}
$$

where $C C^{\text {policy }}$ is an index of climate change policy, State is a measure of statehood experience covering the period 1-1800AD, CommonLawLO is a dummy variable for countries classified as having a British common law tradition, MixedLawLO is a dummy variable for countries classified as having a mixed (i.e., a combination of common and civil) law traditions, $c v^{\prime}$ is a set of control variables included in regressions to allow for the influence of some contemporary and geographic effects, and $\varepsilon$ is an unobserved error term. "Other legal origins" is the excluded group, which includes 39 French and 3 German civil law countries.

Mixed legal tradition refers to those jurisdictions that have inherited both elements of common law and civil law. For instance, South Africa and Sri Lanka are coded as jurisdictions having a mixed legal tradition since they were initially colonized by the Netherlands and hence had inherited some form of civil law tradition. However, this legal system was partially replaced with common law when they were subsequently conquered by England (Klerman et al., 2011). Importantly, the mixed legal heritage arose due to exogenously determined events from the colonies' perspectives.

As discussed in the previous section, our main variable of interest is the interaction term State $\times$ CommonLawLO. The interaction term is expected to carry a negative sign due to the proposition that, relative to civil law countries, common law countries equipped with stronger state capacity impose less stringent climate change rules and regulations.

It is important to highlight that our estimations include only former colonies, which are not OECD members. This consideration is relevant since colonizers typically imposed a system of law upon their colonies. The legal structures imposed on former colonies under colonialism are therefore exogenously determined. By contrast, development of the legal systems in the origin countries, such as England, France, and Germany, was influenced by their own economic, cultural and political factors, and hence is endogenously determined. 
Countries which adopted foreign legal systems voluntarily, such as Ethiopia, Japan, Thailand and Turkey, present similar endogeneity issues since they adopted a legal system, primarily French and German, which was deemed favorable for improving their economic conditions. Hence, a major advantage associated with the use of only former colonies in our analysis is that the exogenous nature of legal systems transplanted by colonialism enables us to interpret our estimates as reflecting the causal impact of legal tradition on climate policies (La Porta et al., 2008; Klerman et al., 2011)

\subsection{Data}

Climate change policy index $\left(C C^{\text {policy }}\right)$. We use the Climate Change Cooperation Index (C3-I) of Bernauer and Böhmelt (2013) as our measure of climate change policy strictness. The C3-I provides times-series cross-section data for up to 172 countries over the period 1996-2008. The index consists of a policy and an emissions component. The policy component, which is used as our main measure of climate change policy, is the aggregate of the following sub-components: (a) whether a country signed the United Nations Framework Convention on Climate Change (UNFCCC) and how soon this was done; (b) whether a country signed the Kyoto Protocol and how soon this was done; (c) whether a country submitted the latest national climate report and if this was done in time; and (d) how often a country made financial contributions to the UNFCCC on time over the period 1996-2008. These four sub-components are summed and an average value of the climate policy index $\left(C C^{\text {policy }}\right)$ is obtained for each country.

State history (State). We use the latest version (version 3.1) of the state history data assembled by Putterman (2004), who provides state antiquity data covering 39 half centuries from 1 AD to 1950 AD for 151 countries. This index of state history gives a score from 0 to 50, reflecting: (1) the presence of a government above the tribal level ( 1 point if yes, 0 points if no); (2) whether this government is foreign or locally based ( 1 point if locally based, 0.5 points if foreign [i.e., the country is a colony], 0.75 if in between [a local government with substantial foreign oversight]; and (3) the proportion of the current territory covered by this government ( 1 point if over $50 \%, 0.75$ points if between $25 \%$ and $50 \%, 0.5$ points if between $10 \%$ and $25 \%, 0.3$ points if less than $10 \%$ ).

To illustrate, state history (State) for the eighteen centuries to 1800 AD is calculated as follows:

$$
\text { State }_{i}=\frac{\sum_{t=1}^{36}(1.05)^{1-t} \bullet S_{i, t}}{\sum_{t=1}^{36}(1.05)^{1-t} \bullet 50}
$$

where $S_{i, t}$ is the state presence for country $i$ for the fifty-year period $t$ (see Putterman and Weil, 2010). The scores on the three questions were multiplied by one another and by 50, so that for a given fifty year period, a country has a score of 50 if it was an autonomous nation, 0 if it had no government above the tribal level, 25 if the entire territory was ruled by a foreign country, and so on. Appendix 2 provides more details on the construction of State and several examples. 
A 5 percent discount rate is applied to each of the half centuries so that less importance is attached to states formed in the more distant past. Our estimates are not sensitive to the use of alternative depreciation rates ranging from 0 to 20 percent. This approach of measuring state antiquity is broadly consistent with Putterman (2008), Putterman and Weil (2010), and more recently, Ang (2013a, b). The index is converted to a scale from 0 to 1 where higher values reflect the presence of a longer state history. Figure 1 shows the dispersion of State across the world for all available countries in the Putterman dataset.

\section{[Figure 1]}

Although data on state history are available up to $1950 \mathrm{AD}$, we measure it only up to 1800 $\mathrm{AD}$ - the period in which colonialism reached its peak. Doing so not only pre-empts the issue of reverse causality from climate policy to state capacity, but the period considered is also more in tandem with the timing when legal systems were imposed on colonies. In the robustness checks, state experiences accumulated up to $1500 \mathrm{AD}$ and $1650 \mathrm{AD}$ are also considered in order to check if the results are driven by the period chosen.

Legal origins $(L O)$. The legal tradition of company law or the commercial code for each country is classified into British common (Common Law LO) or Mixed (Mixed Law LO), with civil law as the excluded category, using binary variables. To do this, we follow the legal tradition classification of Klerman et al. (2011). The advantage of using this classification, as opposed to the more traditional classification approach of La Porta et al. (1998), is that it enables us to identify colonies which were influenced by both civil and common legal structures (Mixed), which may have some bearing on the results. Although Klerman et al. (2011) are legal scholars, who are expected to have detailed insights into countries legal histories, we also consider the more widely adopted legal system classification of La Porta et al. (2008) in the robustness analysis.

After assembling the various sources of data, 78 observations remain. The sample size is mainly constrained by the inclusion only of former colonies in the analysis. Table A2 provides a list of these countries, including legal origin and values of the State measure. Table 1 provides the summary statistics for the key variables used in the estimations.

\section{[Table 1]}

A simple comparison between common law and civil law countries with similar levels of State, such as Malaysia and Nigeria (common law; State $=0.585$ and $0.544 ; C C^{\text {policy }}=36.923$ and 30.082 , respectively) vs. Armenia and Tajikistan (civil law; State $=0.561$ and $0.524 ; C C^{\text {policy }}=49.279$ and 53.267, respectively) indicates that common law countries tend to have weaker climate change policies. However, countries with no statehood experience in $1800 \mathrm{AD}$ (State $=0.00$ ) such as Zambia (common law; $\left.C C^{\text {policy }}=25.521\right)$ and Gabon (civil law; $C C^{\text {policy }}=28.869$ ) exhibit only a small difference in $C C^{\text {policy }}$.

Figure 2 shows the overall association between climate change policy index and statehood experience. Figure 3 exhibits the various relationships between climate change policy index and 
statehood experience across different types of legal tradition. Consistent with our prediction, these diagrams provide preliminary evidence that State and $C C^{\text {policy }}$ are negatively correlated in countries that have the common law legal system. There is, however, no clear relationship between these variables for countries with "mixed" legal traditions.

[Figure 2]

However, it is necessary to check whether there is any difference in outcomes in colonies that did not have any statehood experience in 1800AD. In this connection, it is worth highlighting that the intercept values of the regression models are quite similar in all three sub-samples. This implies that countries which lacked any statehood experience in 1800 AD are likely to end up adopting more or less the same level of stringency in climate change policies. This empirical observation reinforces our proposition that how each type of legal tradition influences climate change policies depends crucially on statehood experience. To confirm this visual inspection, we perform an F-test on the equality of the intercept coefficients for the models that include common law countries only and civil law countries only (their respective intercept coefficients are 36.288 and 30.102). The test-statistic obtained from the nested regression model is $2.590(\mathrm{p}=0.113)$, suggesting that the intercept values are not statistically different.

\section{Results}

\subsection{Main findings}

The estimation results of Eq. (1) are presented in Table 2. We consider several alternative specifications in which the main covariates are entered with different combinations in the regressions to ensure that the results are not driven by any particular model specification. In particular, column (1) considers only the effect of statehood whereas column (2) includes only the legal origin dummies. We do not find any evidence in support of the notion that the variation in climate change policy across countries can be solely accounted for by differences in statehood or legal traditions.

\section{[Table 2]}

Finally, the last column in Table 2 provides the full specification by adding common and mixed legal tradition and their interactions with state history. This complete specification will be used as our baseline model for robustness checks of the results. The results indicate that the interaction between statehood and the common law dummy is significantly correlated with climate change policy with the expected negative sign. This correlation is found to be statistically significant at the 1 percent level. Thus, the results suggest that a longer history of statehood experience at the time of colonization inflates the difference between civil law and common law countries' stringency of climate change policy. The effects are economically meaningful.

The results in column (3) suggest that at the mean value of State, the presence of common law legal origin is associated with a change in $C C^{\text {policy }}$ by $(6.186-0.32 \times 28.069=)-2.796$, equal to a 
decline by 0.26 s.d.. At one s.d. above the mean of State (0.58), the marginal change in $C C^{\text {policy }}$ equals -10.09 , equivalent to 0.95 s.d. All other things being equal, this is equivalent to switching policy from the one in Gambia $\left(C C^{\text {policy }}=33.53\right)$ to the one in Bangladesh $\left(C C^{\text {policy }}=23.44\right)$. This may help explain why common law country Sudan, which had a relatively extensive state experience in $1800 \mathrm{AD}$ (State $=0.703 ; 2.20$ s.d. above the mean), had $C C^{\text {policy }}=21.43$ (1.31 s.d. below the mean).

Statehood experience is found to be significantly correlated with climate change policy, with a positive sign consistent with our prediction. We also find that while the mixed legal system dummy variable is statistically insignificant, its' interaction with statehood is weakly significant in differentiating the variation in climate change policy observed across countries. On the whole, the results presented in Table 2 lend some initial (strong) support to our hypothesis that the stringency of climate change policy can be predicted by the strength of the interaction between statehood and common law legal heritage.

Figure 4 shows the partial regression line for the correlation between climate change policy and the interaction between state experience and common law system, while controlling for the influence of other variations stated in Eq. (1). Evidently, the partial regression line shows a strong negative correlation between the variables, thus reinforcing the findings in Table 2.

[Figure 4]

\subsection{Controlling for other effects}

To ensure that the above results are not confounded by the influence of some other effects and that the early advantage conferred by statehood is not proxying some forms of geographic characteristics, we include several control variables in the regressions and report the results in Table 3. The nongeographic variables include manufacturing output ratio, per capita real income, democratic capital, two indices of institutional quality and an index of ethnolinguistic fractionalization. Controlling for these effects is necessary since they may be correlated with statehood, legal origins and the outcome variable. ${ }^{6}$ Geographic measures that have been argued to be potentially influential for economic outcomes including latitude, landlockedness, mean elevation, distance to the nearest coast or river, and precipitation. These are also controlled for in the regressions. Definitions and sources of these variables are given in Appendix 1.

\section{[Table 3]}

Columns (1) and (2) add the contemporary measures individually. Column (3) includes democratic capital stock. Column (4) controls for the effects of institutions (control of corruption and political stability), column (5) controls for ethnolinguistic fractionalization, and column (6) includes some additional effects of geography. The last column includes all control variables simultaneously.

\footnotetext{
${ }^{6}$ One may suspect that statehood experience may be highly correlated with democratic capita and economic development. Their correlations are surprisingly low: -0.121 between State and GDP per capita and -0.138 between State and democratic capital.
} 
It is evident that the coefficients of our core variable of interest, State $x$ Common Law LO, vary only slightly from the baseline estimate reported in the last column of Table 2 when the effects of manufacturing output, democratic capital (discounted history of democracy), ethnolinguistic fragmentation and geography are allowed for in the regressions (columns (1), (3), (5) and (6)). In these models, the effect of State $x$ Common Law LO remains precisely estimated and is at least significant at the 5 percent significance level.

In absolute terms, the coefficient of State $x$ Common Law LO falls to 20.88 when per capita income is included as a control variable (column (2)). This result is not surprising given that prior studies have shown that state history and climate change policy are both significantly correlated with economic development. Similar findings are obtained when two measures of institutional quality are included as additional control variables in column (4). Nevertheless, the significant effect of State x Common Law LO prevails even after we control for the effect of income level or institutions.

In column (7), we add all control variables jointly into the specification. We find that State $x$ Common Law LO continue to exert a strong explanatory power on climate change policy. This effect is found to be significant at the 5 percent level.

\subsection{Alternative statehood periods}

Next, we consider several alternative statehood periods to shed further light on the results. The estimations here include all the geographic controls used earlier, and are reported in Table 4. Columns (1) and (3) consider statehood only up to $1500 \mathrm{AD}$ and $1650 \mathrm{AD}$, respectively. This is done to ensure that our results are not driven by states formed during the European colonial period since the 16th century. Interestingly, the results indicate that the absolute size of the coefficient on State $x$ Common Law LO declines when the alternative dates are used, rather than the period 1-1800 $\mathrm{AD}$ as done previously in Tables 2 and 3. In particular, the coefficient sizes decline by 4 percent when statehood up to $1650 \mathrm{AD}$ is considered, and by 8 percent when statehood up to $1500 \mathrm{AD}$ is used (the estimates are benchmarked against column (6) of Table 3, which included the geographic controls). These findings imply that a longer statehood confers a stronger state capacity, which enables legal philosophies to develop deeper roots in society and the legal approach used has a greater policy impact. Importantly, the statistical significance of the State $x$ Common Law LO interaction remains largely intact, suggesting that our main findings are unlikely to be driven by the formation of states due to the Western colonization.

\section{[Table 4]}

To ensure that the results are not driven by the exclusion of the remaining statehood period, we also add statehood 1501-1800 AD to the model in column (1) and statehood 1651-1800 AD to the specification in model (3). As shown in the results reported in columns (2) and (4), respectively, we obtain very similar findings. 
In column (5), we measure statehood experience by considering only the presence of states for the period 1751-1800 AD. Doing so enables us to check whether it is the long-term statehood experience or the state presence at the peak of colonialism that matters. Interestingly, the estimates show that climate change policy strictness is unrelated to the state presence during this period. This finding therefore provides further credence to our proposition that the ability of a country to implement the legal philosophies transplanted by its colonial powers depends on the length of its statehood experience.

The results in column (6), which uses statehood from 1 to $1750 \mathrm{AD}$, confirm our previous finding that the length of statehood matters. In column (7), we show the results in column (5) are unchanged when state history up to $1750 \mathrm{AD}$ is controlled for.

\subsection{Further Robustness Checks}

Some further sensitivity checks are in order, and the results are reported in Table 5. First, we use the legal tradition classification of La Porta et al. (2008) to check if our results are robust to a coding method that is more widely used in the literature. The key difference between these two coding approaches relates to the classification of some jurisdictions as "mixed" by Klerman et al. (2011), which is not done by La Porta et al. (2008). Consequently, Mixed Law LO and State x Mixed Law $L O$ are excluded from the regression for this sensitivity check. In our sample of 78 countries, only nine classifications are different. In Klerman et al. (2011), eight of these countries (i.e., Botswana, Cyprus, Guyana, Israel, Lesotho, South Africa, Sri Lanka and Zimbabwe) are classified as having a mixed system and one (i.e., Swaziland) as having adopted the French legal system, whereas La Porta et al. (2008) treat all of them as having British common law tradition. Hence, in principle, we should not expect much variation in the results since the common law dummy variables based on these two different coding procedures yield a correlation coefficient of 0.78 . This conjecture is confirmed in the estimate reported in column (1).

\section{[Table 5]}

We include continent fixed effects in column (2) in order to ensure that the results are not being spuriously driven by unobserved time-invariant region-specific characteristics. Moreover, countries within the same continents tend to have similar colonization history and state performance, and these arbitrary correlations may bias our results. To address this concern, standard errors are clustered by continent to allow for these patterns within but not across continents. That is, the observations are assumed to be independent across continents but not within continents. The estimates in column (2), however, remain largely insensitive to this consideration.

Next, our results may be influenced by the presence of some influential observations such as Fiji, Korea and Uzbekistan. Since there is no compelling reason to exclude them from the estimations, we perform the robust regression analysis, which is a form of weighted regression technique that takes into account of the presence of extreme data points (see, e.g., Andersen, 2008). The results reported in column (3) indicate that our main findings prevail. We have also tried to separately exclude 
the low statehood experience outlier (i.e., Fiji) and the two high statehood experience outliers (i.e., South Korea and Uzbekistan) from the estimations, but the coefficients of interest remain significant at the $5 \%$ level. When all three influential observations are removed, the coefficient of interest is still significant at the $10 \%$ level. The additional results are not reported to conserve space (available upon request).

Additionally, our results may potentially be driven by the failure to control for the initial conditions of colonization. In particular, civil law countries were previously colonized mainly by France, Portugal and Spain whereas common law countries by Great Britain. These countries developed different colonial models, based on differentials in endowment factors in the colonies, which had significant bearing on settlement decisions, institutional building (inclusive or exclusive), and consequently the legacies they left in the post-colonialism era (see also Sokoloff and Engerman, 2000; Acemoglu et al., 2001).

For instance, the Spanish colonizers mostly settled in the most politically and economically advanced regions (i.e., those with older states), whereas the British colonizers did largely the opposite. Consequently, the civil law variable may be a proxy for endowment factors in precolonial areas such as the statehood experience. In this connection, we do not find this conjecture supported by our data, given that statehood experience and legal origins are only weakly related (the correlation is only 0.15 between State and French civil law legal origin dummy).

Nevertheless, we cannot rule out the possibility that significantly different mean values of State exist between civil law and common law countries, thus reflecting the fact that endowments shape colonial institutional building. That is, if countries with a civil law tradition indeed have longer statehood experience than those with a common law origin due to the pursuit of different colonization strategy, then what we find would not reflect the effect of legal origins conditional upon the level of statehood experience, but rather the fact that statehood experience is longer in civil law countries due to different colonization strategy. We address this concern in the following ways.

First, in order to compare the mean values of State between civil law and common law countries, we perform the two-group mean-comparison test. This is essentially a t-test designed to compare means of the same variable between two groups. When the independent variable is chosen to be common law so that the two groups are common law $(\mathrm{N}=24)$ and non-common law $(\mathrm{N}=54)$ group, the t-statistic is 1.72 and the corresponding p-value is 0.09 . When a comparison is made between French civil law countries versus others, the p-value is 0.189 . On these grounds, we conclude that the difference of means in State between civil law and common law countries is statistically not different from 0 .

Second, we directly control for endowment effects using the settler mortality measure of Acemoglu et al. (2001). Doing so, however, does not change the results in any significant manner (see column (4)). Note that the results are almost unchanged when the improved measure of settler mortality rate provided by Albouy (2012) is used (results unreported to conserve space; available upon request). Third, in order to account for the possibility that legal origins are shaped by colonial strategy, which may confound our results, we include four colonial origin dummies (British, French, 
Portuguese and Spanish with other European as the excluded group). Our main results prevail (see column (5)).

We also provide some additional estimation by considering the individual components of the aggregate statehood experience index. Does one component of the index drive our results, or do all contribute? The overall index considered so far is based on three sub-components, which capture the presence of a government above the tribal level $\left(S T^{P R E S E N C E}\right)$, whether this government is foreign or locally based $\left(S T^{A U T O N O M Y}\right)$, and the proportion of the current territory covered by this government $\left(S T^{C O V E R A G E}\right)$. The presence of a state above the tribal level appears highly relevant as a measure of the administrative capacity to adopt the colonizer's legal philosophy, for example. Appendix 2 provides the details of the individual components.

The results provided in the last three columns show that coefficients of the interaction between State and common law dummy are significant in all cases, suggesting that all dimensions of statehood experience matter. The interaction between $S T^{C O V E R A G E}$ (which captures the extent to which the territory of the modern country under consideration was ruled by a particular government) and common law dummy is found to have the most significant correlation. ${ }^{7}$

\subsection{Endogeneity Issues}

As is common in all empirical studies, it would be necessary to correct for the endogeneity of statehood experience due to measurement errors or omitted variable bias. In this case, it is expected that the interaction between statehood experience and the legal origin dummies are also endogenous regressors. In order to isolate the exogenous variation in statehood experience, we use the timing of agricultural transition as the instrument. The data are obtained from Putterman (2006).

This identification strategy is based on the well-known proposition of Diamond (1997) that agricultural transition significantly increased food supply, which enabled settled agricultural villages with small-scale political entities governed by supra-tribal authorities to compound into larger polities, leading to the emergence of fully-fledged states. Dramatic improvements in agricultural productivity also enabled polities to enhance their fiscal capacity through raising more tax revenues. Hence, the onset of the institutionalization of power relations triggered by the Neolithic transition was a key catalyst for state formation and the development of state capacity. This hypothesis suggests that an earlier transition to agriculture is expected to have a positive influence on the length of statehood experience.

The instrumental variable results and the first-stage regressions are presented in Table 6 . It is evident that, in line with its OLS counterpart, the interaction term between statehood experience and common law legal origin is found to have a significant effect (columns (4)). In the first-stage regressions, the timing of agricultural transition is found to be a significant determinant of statehood experience, consistent with our prediction (column (1)). Similarly, the interaction of agricultural transition and legal origins significantly explains the interaction of statehood experience and legal origins (columns (2) and (3)).

\footnotetext{
${ }^{7}$ Territorial integrity appears important for building bureaucratic capacity, possibly due to the associated stability.
} 


\section{[Table 6]}

The first-stage F-statistics provide supportive evidence that agricultural transition is a suitable instrument. Given that multiple endogenous regressors are used, we also adopt the procedure of Shea (1997) for testing instrument relevance. This approach tests for the strength of the relationship between every endogenous variable and the excluded instruments, after partialing out the included instruments and other endogenous variables. A small value of the Shea partial R-squared would indicate that the instruments lack sufficient relevance to explain all the endogenous regressors. The Shea's partial R-squared statistics range from 0.114 to 0.455 , providing evidence that the instruments are quite strongly correlated with the endogenous variables, and hence are sufficiently relevant to explain the endogenous regressors.

Additionally, we also use the Anderson-Rubin (1949) method for testing the significance of the endogenous regressors in the structural equation. This approach is robust to weak instruments. The test rejects the null hypothesis that the coefficients of the excluded instruments are jointly equal to zero at the $5 \%$ level of significance, thus providing evidence that the endogenous regressors are relevant even in the presence of weak instruments.

To further increase the credibility of the results, we also perform the fractionally resampled Anderson-Rubin $(F A R)$ test, using the procedure developed by Berkowitz et al. (2012), to test the joint significance of the endogenous regressors in our IV estimations. This weak exogeneity test is performed under the assumption that our instrument nearly, but not completely, satisfies the exclusion restriction. A rejection of the null implies that our instrument is endogenous. Clearly, the results indicate that the exclusion restriction assumption is not violated.

Although the IV estimates give consistent results, Bun and Harrison (2014) show that, under some general conditions, the OLS estimates of interaction terms are consistent and asymptotically normally distributed and that standard OLS inference is valid for their coefficients. ${ }^{8}$ Given that OLS estimation and inference are reliable, the potential gains for using instruments are limited since the assumption of exclusion restriction cannot be fully satisfied. In light of this, the OLS estimator is our preferred approach.

\subsection{Alternative environmental policy measures}

Our analysis has so far focused only on testing the interaction effect of statehood experience and legal origins on climate change policy. Our results indicate that common law countries with experienced statehood are less inclined to adopt stringent climate change policies. Can the same effect be observed on additional environmental policy outcomes, including those that address more local or regional pollution problems? We adopt the same regression framework and consider four other environmental protection variables.

First, in addition to the $C C^{\text {policy }}$ index used above, Bernauer and Böhmelt (2013) also provide a more encompassing index of climate change policy outcomes, CCCI, which takes into consideration

\footnotetext{
8 These conditions include allowing for continuous and discrete interaction terms, correlation between endogenous and exogenous regressors, conditional heteroskedasticity and non-normality (Bun and Harrison, 2014).
} 
the level and trend effects of emissions. We use this overall index as the dependent variable in column (1), Table 7 . Note, however, that the $C C^{\text {policy }}$ is our preferred measure since emissions are not necessarily policy-determined and are often affected by other hard-to-control-for socio-economic and political factors, and hence are more likely to subject our results to endogeneity bias. As a second measure of environmental policy stringency we use the (inverse) maximum lead content per gallon of gasoline in 1996 collected from Lovei, 1998) in column (2); Reyes (2015) discusses some health risks associated with lead exposure. Next, in column (3) we use the comprehensive environmental performance index of Hsu et al. (2014), which uses a broad spectrum of indicators to measure countries' protection of human health from environmental harm and the protection of ecosystems in year 2012. Finally, we also use a measure of the stringency of environmental regulations in the agricultural sector for year 1990 from Eliste and Fredriksson (2002) in the last column. This seeks to capture the overall regulatory framework (policies, legislation, and enforcement) addressing environmental problems associated with the agricultural sector.

\section{[Table 7]}

The results in Table 7 do not alter our main findings markedly given the fact that the coefficient of State x Common Law LO remains significant at conventional levels with a negative sign. These results suggest that our findings may apply also to more local or regional environmental problems.

\section{Summary and Conclusions}

A country's histories of, for example, agricultural development, urbanization, money, taxation, and government administration, all build stocks of human capital and experience. The cumulative experience with statehood influences a country's ability to consolidate power and create a capable bureaucracy, which may be summed up as "state capacity." We argue that the level of long term statehood experience should influence the propensity of former colonies to absorb and implement the legal frameworks transplanted by the colonial powers.

This paper tests the hypothesis that the influence of former colonies' legal heritage on modern climate change policies is conditional on their historical experience with statehood (state capacity). Our empirical work provides support for this hypothesis. The positive difference in the climate change policy stringency in former colonies with common law and civil law systems is enlarged by a longer history of statehood experience. Consistent with this finding, we also find that legal origin has no effect on countries which had no statehood experience around the time of colonization. We obtain similar results also for several alternative environmental policies. Our results suggest that long term historical processes should not be ignored when studying and designing modern policymaking, in particular those addressing climate change. 


\section{References}

Acemoglu, D., García-Jimeno, C. \& Robinson, J.A. (2015). 'State Capacity and Economic Development: A Network Approach', American Economic Review 105, 2364-2409.

Acemoglu, D., Johnson, S. \& Robinson, J.A. (2001). 'The Colonial Origins of Comparative Development: An Empirical Investigation', American Economic Review 91, 1369-1401.

Albouy, D.Y. (2012). 'The Colonial Origins of Comparative Development: An Empirical Investigation: Comment', American Economic Review 102, 3059-3076.

Alesina, A., Devleeschauwer, A., Easterly, W., Kurlat, S. \& Wacziarg, R. (2003). 'Fractionalization', Journal of Economic Growth 8, 155-194.

Andersen, R. (2008) Modern Methods for Robust Regression (London: Sage Publications).

Ang, J.B. (2013a). 'Are Modern Financial Systems Shaped by State Antiquity?' Journal of Banking and Finance 37, 4038-4058.

Ang, J.B. (2013b). 'Institutions and the Long-run Impact of Early Development', Journal of Development Economics 105, 1-18.

Barbier, E.B., Damania, R. \& Leonard, D. (2005). 'Corruption, Trade and Resource Conversion', Journal of Environmental Economics and Management 50, 276-299.

Becerra, O., Cavallo, E.A. \& Scartascini, C. (2012). 'The Politics of Financial Development: The Role of Interest Groups and Government Capabilities', Journal of Banking and Finance 36, 626-643.

Berkowitz, D., Caner, M. \& Fang, Y. (2012). 'The Validity of Instruments Revisited', Journal of Econometrics 166, 255-266.

Berkowitz, D., Pistor, K. \& Richard, J.-F. (2003). 'Economic Development, Legality, and the Transplant Effect', European Economic Review 47, 165-195.

Bernauer, T. \& Böhmelt, T. (2013). 'National Climate Policies in International Comparison: The Climate Change Cooperation Index', Environmental Science and Policy 25, 196-206.

Besley, T., Ilzetzki, E. \& Persson, T. (2013). 'Weak States and Steady States: The Dynamics of Fiscal Capacity', American Economic Journal: Macroeconomics 5, 205-235.

Besley, T. \& Persson, T. (2009). 'The Origins of State Capacity: Property Rights, Taxation, and Politics', American Economic Review 99, 1218-1244.

Besley, T. \& Persson, T. (2011) Pillars of Prosperity. The Political Economy of Development Clusters (Princeton, NJ: Princeton University Press).

Botero, J.C., Djankov, S., Porta, R.L., Lopez-de-Silanes, F. \& Shleifer, A. (2004). 'The Regulation of Labor', Quarterly Journal of Economics 119, 1339-1382.

Bun, M.J.G. \& Harrison, T.D. (2014). 'OLS and IV Estimation of Regression Models Including Endogenous Interaction Terms', UvA-Econometrics Working Papers 14-02, Universiteit van Amsterdam, Dept. of Econometrics.

Burkett, J.P., Humblet, C. \& Putterman, L. (1999). 'Preindustrial and Postwar Economic Development: Is There a Link?' Economic Development and Cultural Change 47, 471-495.

CIA (2015) 'The Central Intelligence Agency World Factbook (https://www.cia.gov/index.html)'. 
Comin, D., Easterly, W. \& Gong, E. (2010). 'Was the Wealth of Nations Determined in 1000 BC?' American Economic Journal: Macroeconomics 2, 65-97.

Congleton, R. (1992). 'Political Institutions and Pollution Control', Review of Economics and Statistics 74, 412-421.

Damania, R., Fredriksson, P.G. \& List, J.A. (2003). 'Trade Liberalization, Corruption, and Environmental Policy Formation: Theory and Evidence', Journal of Environmental Economics and Management 46, 490-512.

David, P.A. (1985). 'Clio and the Economics of QWERTY', American Economic Review 75, 332-337.

Diamond, J. (1997) Guns, Germs and Steel: The Fates of Human Societies (New York: Norton).

Djankov, S., La Porta, R., Lopezde-Silanes, F. \& Shleifer, A. (2003). 'Courts', Quarterly Journal of Economics 118, 453-517.

Djankov, S., Porta, R.L., Lopez-de-Silanes, F. \& Shleifer, A. (2002). 'The Regulation of Entry', Quarterly Journal of Economics 117, 1-37.

Eliste, P. \& Fredriksson, P.G. (2002). 'Environmental Regulations, Transfers, and Trade: Theory and Evidence', Journal of Environmental Economics and Management 43, 234-250.

Farzin, H.Y. \& Bond, C.A. (2006). 'Democracy and Environmental Quality', Journal of Development Economics 81, 213-2354.

Fredriksson, P.G. \& Neumayer, E. (2013). 'Democracy and Climate Change Policies: Is History Important?' Ecological Economics 95, 11-19.

Fredriksson, P.G. \& Svensson, J. (2003). 'Political Instability, Corruption and Policy Formation: The Case of Environmental Policy', Journal of Public Economics 87, 1383-1405.

Fredriksson, P.G. \& Wollscheid, J.R. (2015). 'Legal Origins and Climate Change Policies in Former Colonies', Environmental and Resource Economics 62, 309-327.

G-Econ (2008) 'Geographically-based Economic Data (http://gecon.yale.edu/), Yale University'.

Gallup, J.L., Mellinger, A.D. \& Sachs, J.D. (2010). 'Geography Datasets', Centre for International Development, Harvard University.

Galor, O. \& Weil, D.N. (2000). 'Population, Technology, and Growth: From Malthusian Stagnation to the Demographic Transition and Beyond', American Economic Review 90, 806-828.

Gennaioli, N. \& Rainer, I. (2007). 'The Modern Impact of Precolonial Centralization in Africa', Journal of Economic Growth 12, 185-234.

Glaeser, E.L. \& Shleifer, A. (2002). 'Legal Origins', Quarterly Journal of Economics 117, 11931229.

Greif, A. (1998). 'Historical and Comparative Institutional Analysis', American Economic Review 88, 80-84.

Hodgson, G.M. (1998). 'The Approach of Institutional Economics', Journal of Economic Literature 36, 166-192.

Hotte, L. \& Winer, S. (2012). 'Environmental Regulation and Trade Openness in the Presence 
of Private Mitigation', Journal of Development Economics 97, 46-57.

Hsu, A., Emerson, J., Levy, M., Sherbinin, A.d., Johnson, L., Malik, O., Schwartz, J. \& Jaiteh, M. (2014) The Environmental Performance Index (New Haven, CT: Yale Center for Environmental Law and Policy).

IPCC (2014) Climate Change 2014: Synthesis Report. Contribution of Working Groups I, II and III to the Fifth Assessment Report of the Intergovernmental Panel on Climate Change (Geneva, Switzerland: IPCC).

Klerman, D. \& Mahoney, P.G. (2007). 'Legal Origin?' Journal of Comparative Economics 35, 278-293.

Klerman, D.M., Mahoney, P.G., Spamann, H. \& Weinstein, M.I. (2011). 'Legal Origin or Colonial History?' Journal of Legal Analysis 3, 379-409.

Kremer, M. (1993). 'Population Growth and Technological Change: One Million B.C. to 1990', Quarterly Journal of Economics 108, 681-716.

La Porta, R., Florencio, L.-d.-S., Shleifer, A. \& Vishny, R.W. (1997). 'Legal Determinants of External Finance', Journal of Finance 52, 1131-1150.

La Porta, R., Florencio, L.-d.-S., Shleifer, A. \& Vishny, R.W. (1998). 'Law and Finance', Journal of Political Economy 106, 1113-1155.

La Porta, R., Lopez-de-Silanes, F. \& Shleifer, A. (2008). 'The Economic Consequences of Legal Origins', Journal of Economic Literature 46, 285-332.

Levine, R. (2005). 'Law, Endowments and Property Rights', Journal of Economic Perspectives 19, 61-88.

List, J.A. \& Sturm, D.M. (2006). 'How Elections Matter: Theory and Evidence from Environmental Policy', Quarterly Journal of Economics 121, 1249-1281.

Lovei, M. (1998). 'Phasing out Lead from Gasoline in Central and Eastern Europe, Health Issues, Feasibility, and Policies', World Bank Technical Paper No. 397.

Marchand, S. (2016). 'The Colonial Origins of Deforestation: An Institutional Analysis', Environment and Development Economics 21, 318-349.

McNeill, J.R. \& McNeill, W.H. (2003) The Human Web: A Bird's-Eye View of World History (New York: Norton).

Michalopoulos, S. \& Papaioannou, E. (2013). 'Pre-Colonial Ethnic Institutions and Contemporary African Development', Econometrica 81, 113-152.

Michalopoulos, S. \& Papaioannou, E. (2014). 'National Institutions and Subnational Development in Africa', Quarterly Journal of Economics 129, 151-213.

Mulligan, C. \& Shleifer, A. (2005). 'The Extent of the Market and the Supply of Regulation', Quarterly Journal of Economics 120, 1445-1473.

North, D.C. (2006) Understanding the Process of Economic Change (Princeton: Princeton University Press).

Nunn, N. \& Puga, D. (2012). 'Ruggedness: The Blessing of Bad Geography in Africa', Review of Economics and Statistics 94, 20-36. 
Oliva, P. (2015). 'Environmental Regulations and Corruption: Automobile Emissions in Mexico City', Journal of Political Economy 123, 686-724.

Oto-Peralías, D. \& Romero-Ávila, D. (2014). 'The Distribution of Legal Traditions around the World: A Contribution to the Legal-Origins Theory', Journal of Law and Economics 57, 561-628.

Ponzetto, G.A.M. \& Fernandez, P.A. (2008). 'Case Law vs. Statute Law: An Evolutionary Comparison', Journal of Legal Studies 37, 379-430.

Putterman, L. (2000). 'Can An Evolutionary Approach to Development Predict Post-War Economic Growth?' Journal of Development Studies 36, 1-30.

Putterman, L. (2004). 'State Antiquity Index (Statehist) Dataset, version 3.1', Brown University.

Putterman, L. (2006). 'Agricultural Transition Year Country Data Set', Brown University.

Putterman, L. (2008). 'Agriculture, Diffusion and Development: Ripple Effects of the Neolithic Revolution', Economica 75, 729-748.

Putterman, L. \& Weil, D.N. (2010). 'Post-1500 Population Flows and the Long-Run Determinants of Economic Growth and Inequality', Quarterly Journal of Economics 125, 1627-1682.

Reyes, J.W. (2015). 'Lead Exposure and Behavior: Effects on Antisocial and Risky Behavior among Children and Adolescents', Economic Inquiry 53, 1580-1605.

Roberts, R. \& Mann, K. (1991) 'Law in Colonial Africa', in Law in Colonial Africa, eds. R. Roberts and K. Mann (Portsmouth, NH: Heinemann), 3-58.

Roe, M.J. (2007). 'Juries and the Political Economy of Legal Origin', Journal of Comparative Economics 35, 294-308.

Schapera, I. (1970) Tribal Innovators: Tswana Chiefs and Social Change, 1795-1940 (New York: Humanities Press).

Shea, J. (1997). 'Instrument Relevance in Multivariate Linear Models: A Simple Measure', Review of Economics and Statistics 49, 348-352.

Sigman, H. (2014). 'Decentralization and Environmental Quality: An International Analysis of Water Pollution Levels and Variation', Land Economics 90, 114-130.

Sokoloff, K.L. \& Engerman, S.L. (2000). 'Institutions, Factor Endowments, and Paths of Development in the New World', Journal of Economic Perspectives 14, 217-232.

Tosh, J. (1978) Clean Leaders and Colonial Chiefs in Lango: The Political History of an East African Stateless Society c. 1800-1939 (Oxford: Oxford University Press).

WDI (2015) World Development Indicators 2015 database (Philadelphia: World Bank).

WGI (2015) World Governance Indicators 2015 Database (Philadelphia: World Bank). 
Table 1: Descriptive statistics of key variables

\begin{tabular}{|c|c|c|c|c|c|}
\hline Variable & Observations & Mean & Std. Dev. & Min. & Max. \\
\hline$C C^{\text {policy }}$ & 78 & 35.35 & 10.64 & 14.49 & 62.74 \\
\hline$C C^{\text {policy }}$ - common law LO & 24 & 33.65 & 9.13 & 18.75 & 56.77 \\
\hline$C C^{\text {policy }}-$ mixed law LO & 12 & 34.23 & 10.12 & 14.49 & 52.16 \\
\hline$C C^{\text {policy }}$ - other LO & 42 & 36.64 & 11.61 & 16.46 & 62.74 \\
\hline State & 78 & 0.32 & 0.26 & 0.00 & 0.93 \\
\hline State - common law LO & 24 & 0.24 & 0.27 & 0.00 & 0.81 \\
\hline State - mixed law LO & 12 & 0.26 & 0.27 & 0.00 & 0.79 \\
\hline Common Law LO & 78 & 0.31 & 0.46 & 0.00 & 1.00 \\
\hline Mixed LO & 78 & 0.15 & 0.36 & 0.00 & 1.00 \\
\hline Other $L O$ & 78 & 0.54 & 0.50 & 0.00 & 1.00 \\
\hline State x Common Law LO & 78 & 0.07 & 0.18 & 0.00 & 0.81 \\
\hline State x Mixed Law LO & 78 & 0.04 & 0.14 & 0.00 & 0.79 \\
\hline State x Other LO & 78 & 0.20 & 0.26 & 0.00 & 0.93 \\
\hline Manufacuring $(\% G D P)$ & 76 & 13.34 & 7.69 & 2.89 & 38.67 \\
\hline Democratic capital & 68 & 0.42 & 0.35 & 0.00 & 1.00 \\
\hline Control of corruption & 78 & 40.98 & 26.39 & 1.46 & 97.57 \\
\hline Political stability & 78 & 37.72 & 26.17 & 0.48 & 90.38 \\
\hline Ethnolinguistic frac & 72 & 0.53 & 0.25 & 0.00 & 0.93 \\
\hline Latitude & 78 & 0.22 & 0.15 & 0.00 & 0.67 \\
\hline Landlocked & 75 & 0.31 & 0.46 & 0.00 & 1.00 \\
\hline Elevation & 78 & 560.83 & 510.29 & 31.64 & 2672.87 \\
\hline Distance to coast & 78 & 429.94 & 454.08 & 3.68 & 1875.13 \\
\hline Precipitation & 78 & 95.10 & 65.63 & 2.91 & 259.95 \\
\hline
\end{tabular}

Notes: The descriptive statistics provided in the table include up to 78 countries used in the baseline regressions. Sources and definition of data are described in the text and the data appendix. 
Table 2: Main results

\begin{tabular}{llll}
\hline Dep. Var. = CC & & $(2)$ & $(3)$ \\
\hline State & $(1)$ & & $17.194^{* *}$ \\
Common Law LO & 5.346 & $(2.188)$ \\
& $(1.027)$ & -2.996 & $(1.56$ \\
Mixed Law LO & & $(-1.155)$ & 5.710 \\
Statex Common Law LO & & -2.409 & $(1.355)$ \\
Statex Mixed Law LO & & $(-0.714)$ & $-28.069^{* * *}$ \\
& & $(-2.914)$ \\
\hline R-squared & & $-23.365^{*}$ \\
Observations & 0.018 & $(-1.743)$ \\
\hline
\end{tabular}

Notes: robust standard errors are used and $t$-statistics are reported in the parentheses. $*, * *$ and $* * *$ indicate significance at the $10 \%, 5 \%$ and $1 \%$ levels, respectively. The intercept estimate is not shown. The omitted legal origin group is "other legal origins", which includes 39 French and 3 German civil law countries. 
Table 3: Robustness analysis: including control variables

\begin{tabular}{|c|c|c|c|c|c|c|c|}
\hline Dep. Var. $=C C^{\text {policy }}$ & (1) & $(2)$ & (3) & (4) & (5) & (6) & (7) \\
\hline State & $\begin{array}{l}12.99 \\
(1.64)\end{array}$ & $\begin{array}{l}14.03^{*} \\
(1.81)\end{array}$ & $\begin{array}{l}13.09 \\
(1.56)\end{array}$ & $\begin{array}{l}15.71^{*} \\
(1.99)\end{array}$ & $\begin{array}{l}13.66^{*} \\
(1.69)\end{array}$ & $\begin{array}{l}15.94^{*} \\
(1.73)\end{array}$ & $\begin{array}{l}6.30 \\
(0.64)\end{array}$ \\
\hline Common Law LO & $\begin{array}{l}5.93^{*} \\
(1.68)\end{array}$ & $\begin{array}{l}2.18 \\
(0.54)\end{array}$ & $\begin{array}{l}3.53 \\
(0.66)\end{array}$ & $\begin{array}{l}1.98 \\
(0.45)\end{array}$ & $\begin{array}{l}5.47 \\
(1.35)\end{array}$ & $\begin{array}{l}7.03 \\
(1.61)\end{array}$ & $\begin{array}{l}5.91 \\
(1.05)\end{array}$ \\
\hline Mixed Law LO & $\begin{array}{l}2.23 \\
(0.54)\end{array}$ & $\begin{array}{l}3.97 \\
(0.85)\end{array}$ & $\begin{array}{l}3.58 \\
(0.71)\end{array}$ & $\begin{array}{l}3.26 \\
(0.79)\end{array}$ & $\begin{array}{l}3.86 \\
(0.80)\end{array}$ & $\begin{array}{l}5.54 \\
(1.07)\end{array}$ & $\begin{array}{l}0.97 \\
(0.15)\end{array}$ \\
\hline State x Common Law LO & $\begin{array}{l}-27.13^{* * *} \\
(-3.00)\end{array}$ & $\begin{array}{l}-20.88^{* *} \\
(-2.11)\end{array}$ & $\begin{array}{l}-22.30^{* *} \\
(-2.01)\end{array}$ & $\begin{array}{l}-21.99^{* *} \\
(-2.15)\end{array}$ & $\begin{array}{l}-24.61^{* *} \\
(-2.39)\end{array}$ & $\begin{array}{l}-28.43^{* *} \\
(-2.60)\end{array}$ & $\begin{array}{l}-25.75^{* *} \\
(-2.16)\end{array}$ \\
\hline State x Mixed Law LO & $\begin{array}{l}-17.43 \\
(-1.30)\end{array}$ & $\begin{array}{l}-25.56^{*} \\
(-1.75)\end{array}$ & $\begin{array}{l}-19.56 \\
(-1.24)\end{array}$ & $\begin{array}{l}-26.22^{*} \\
(-1.76)\end{array}$ & $\begin{array}{l}-20.68 \\
(-1.41)\end{array}$ & $\begin{array}{l}-21.42 \\
(-1.52)\end{array}$ & $\begin{array}{l}-20.08 \\
(-1.11)\end{array}$ \\
\hline Manufacuring $(\%$ GDP $)$ & $\begin{array}{l}0.54^{* * *} \\
(3.03)\end{array}$ & & & & & & $\begin{array}{l}0.55^{* * *} \\
(2.80)\end{array}$ \\
\hline Income per capita (logged) & & $\begin{array}{l}2.50^{* *} \\
(2.39)\end{array}$ & & & & & $\begin{array}{l}2.07 \\
(1.24)\end{array}$ \\
\hline Democratic capital & & & $\begin{array}{l}1.43 \\
(0.26)\end{array}$ & & & & $\begin{array}{l}2.64 \\
(0.55)\end{array}$ \\
\hline Control of corruption & & & & $\begin{array}{l}3.79^{*} \\
(1.76)\end{array}$ & & & $\begin{array}{l}4.29 \\
(1.14)\end{array}$ \\
\hline Political stability & & & & $\begin{array}{l}-0.55 \\
(-0.28)\end{array}$ & & & $\begin{array}{l}-0.71 \\
(-0.27)\end{array}$ \\
\hline Ethnolinguistic frac & & & & & $\begin{array}{l}-6.98 \\
(-1.30)\end{array}$ & & $\begin{array}{l}3.34 \\
(0.48)\end{array}$ \\
\hline Latitude & & & & & & $\begin{array}{l}0.03 \\
(0.40)\end{array}$ & $\begin{array}{l}0.09 \\
(0.86)\end{array}$ \\
\hline Landlocked & & & & & & $\begin{array}{l}-0.64 \\
(-0.19)\end{array}$ & $\begin{array}{l}-0.22 \\
(-0.05)\end{array}$ \\
\hline Elevation & & & & & & $\begin{array}{l}0.00 \\
(0.99)\end{array}$ & $\begin{array}{l}0.00 \\
(0.75)\end{array}$ \\
\hline Distance to coast & & & & & & $\begin{array}{l}0.00 \\
(0.13)\end{array}$ & $\begin{array}{l}0.01 \\
(1.07)\end{array}$ \\
\hline Precipitation & & & & & & $\begin{array}{l}-0.00 \\
(-0.01)\end{array}$ & $\begin{array}{l}-0.00 \\
(-0.14)\end{array}$ \\
\hline R-squared & 0.243 & 0.195 & 0.089 & 0.184 & 0.150 & 0.155 & 0.339 \\
\hline Observations & 77 & 77 & 68 & 78 & 72 & 75 & 65 \\
\hline
\end{tabular}

Notes: Robust standard errors are used and $t$-statistics are reported in the parentheses. ${ }^{*},{ }^{* *}$ and $* * *$ indicate significance at the $10 \%, 5 \%$ and $1 \%$ levels, respectively. The intercept estimate is not shown. The omitted legal origin group is "other legal origins", which includes 39 French and 3 German civil law countries. The following countries are excluded due to unavailability of data: Israel (column (1)), Zimbabwe (column (2)), Barbados, Grenada, New Zealand, Sao Tome and Principe, Canada, United States, South Korea, Australia, Israel and Seychelles (column (3)), Democratic Republic of the Congo, Kyrgyzstan, Sao Tome \& Principe, Barbados, Seychelles and Grenada (column (5)), and Barbados, Grenada and Seychelles (column (6)). The last column includes all control variables and hence has only 65 observations. 
Table 4: Alternative statehood periods

\begin{tabular}{|c|c|c|c|c|c|c|c|}
\hline & $(1)$ & $(2)$ & $(3)$ & $(4)$ & $(5)$ & $(6)$ & $(7)$ \\
\hline Dep. Var. $=C C^{\text {policy }}$ & $\begin{array}{l}\text { State his- } \\
\text { tory up to } \\
\text { 1500AD } \\
\text { (State } 1)\end{array}$ & $\begin{array}{l}\text { State his- } \\
\text { tory up to } \\
1500 A D \\
(\text { State } 1) \\
\& \quad 1501- \\
1800 A D \\
\text { (State } 2)\end{array}$ & $\begin{array}{l}\text { State his- } \\
\text { tory up to } \\
1650 \mathrm{AD} \\
(\text { State } 1)\end{array}$ & $\begin{array}{l}\text { State his- } \\
\text { tory up to } \\
1650 A D \\
(\text { State } 1) \\
\& \quad 1651- \\
1800 A D \\
\text { (State } 2)\end{array}$ & $\begin{array}{l}\text { State } \\
\text { history } \\
1751- \\
\text { 1800AD } \\
\text { (State 2) }\end{array}$ & $\begin{array}{l}\text { State his- } \\
\text { tory up to } \\
1750 A D \\
(\text { State } 1)\end{array}$ & $\begin{array}{l}\text { State his- } \\
\text { tory up to } \\
1750 A D \\
(\text { State } 1) \\
\& \quad 1751- \\
\text { 1800AD } \\
\text { (State 2) }\end{array}$ \\
\hline State 1 & $\begin{array}{l}12.960 \\
(1.596)\end{array}$ & $\begin{array}{l}9.893 \\
(1.135)\end{array}$ & $\begin{array}{l}14.299 \\
(1.655)\end{array}$ & $\begin{array}{l}11.603 \\
(1.217)\end{array}$ & & $\begin{array}{l}15.503^{*} \\
(1.726)\end{array}$ & $\begin{array}{l}15.409 \\
(1.528)\end{array}$ \\
\hline Common Law LO & $\begin{array}{l}3.873 \\
(1.091)\end{array}$ & $\begin{array}{l}6.404 \\
(1.097)\end{array}$ & $\begin{array}{l}5.415 \\
(1.395)\end{array}$ & $\begin{array}{l}6.763 \\
(1.045)\end{array}$ & $\begin{array}{l}7.031 \\
(0.994)\end{array}$ & $\begin{array}{l}6.539 \\
(1.565)\end{array}$ & $\begin{array}{l}5.596 \\
(0.808)\end{array}$ \\
\hline Mixed Law LO & $\begin{array}{l}2.601 \\
(0.591)\end{array}$ & $\begin{array}{l}9.099 \\
(1.233)\end{array}$ & $\begin{array}{l}3.929 \\
(0.843)\end{array}$ & $\begin{array}{l}8.757 \\
(1.022)\end{array}$ & $\begin{array}{l}2.917 \\
(0.339)\end{array}$ & $\begin{array}{l}5.046 \\
(1.022)\end{array}$ & $\begin{array}{l}3.321 \\
(0.389)\end{array}$ \\
\hline State $1 \times$ Common Law LO & $\begin{array}{l}- \\
26.194^{* * *} \\
(-2.737)\end{array}$ & $\begin{array}{l}-24.362^{*} \\
(-1.849)\end{array}$ & $\begin{array}{l}- \\
27.307^{* * *} \\
(-2.680)\end{array}$ & $\begin{array}{l}-28.707^{*} \\
(-1.919)\end{array}$ & & $\begin{array}{l}-28.166^{* *} \\
(-2.643)\end{array}$ & $\begin{array}{l}-34.780^{* *} \\
(-2.026)\end{array}$ \\
\hline State $1 \times$ Mixed Law LO & $\begin{array}{l}-15.928 \\
(-1.351)\end{array}$ & $\begin{array}{l}-7.234 \\
(-0.588)\end{array}$ & $\begin{array}{l}-18.612 \\
(-1.470)\end{array}$ & $\begin{array}{c}-13.139 \\
(-0.986)\end{array}$ & & $\begin{array}{c}-20.792 \\
(-1.539)\end{array}$ & $\begin{array}{l}-21.804 \\
(-1.561)\end{array}$ \\
\hline State 2 & & $\begin{array}{l}6.660 \\
(0.810)\end{array}$ & & $\begin{array}{l}5.888 \\
(0.667)\end{array}$ & $\begin{array}{l}0.186 \\
(0.990)\end{array}$ & & $\begin{array}{l}0.025 \\
(0.136)\end{array}$ \\
\hline State $2 \times$ Common Law LO & & $\begin{array}{l}-5.317 \\
(-0.397)\end{array}$ & & $\begin{array}{l}-1.330 \\
(-0.086)\end{array}$ & $\begin{array}{l}-0.328 \\
(-1.311)\end{array}$ & & $\begin{array}{l}0.124 \\
(0.349)\end{array}$ \\
\hline State $2 \times$ Mixed Law LO & & $\begin{array}{c}-21.138 \\
(-1.209)\end{array}$ & & $\begin{array}{l}-14.029 \\
(-0.720)\end{array}$ & $\begin{array}{l}-0.146 \\
(-0.426)\end{array}$ & & $\begin{array}{l}0.098 \\
(0.294)\end{array}$ \\
\hline R-squared & 0.148 & 0.166 & 0.152 & 0.164 & 0.094 & 0.156 & 0.163 \\
\hline Observations & 75 & 75 & 75 & 75 & 75 & 75 & 75 \\
\hline Geographic controls & YES & YES & YES & YES & YES & YES & YES \\
\hline
\end{tabular}

Notes: Robust standard errors are used and $t$-statistics are reported in the parentheses. ${ }^{*},{ }^{* *}$ and $* * *$ indicate significance at the $10 \%, 5 \%$ and $1 \%$ levels, respectively. The intercept estimate is not shown. The omitted legal origin group is "other legal origins", which include 39 French and 3 German civil law countries. The geographic controls included are latitude, landlockedness, mean elevation, distance to the nearest coast or river, and precipitation. The estimations exclude Barbados, Grenada, and Seychelles. 
Table 5: Further robustness checks

\begin{tabular}{|c|c|c|c|c|c|c|c|c|}
\hline & (1) & (2) & (3) & (4) & (5) & (6) & (7) & $(8)$ \\
\hline & $\begin{array}{lr}\text { La } & \text { Porta } \\
\text { et } & \text { al. } \\
\text { data } & \end{array}$ & $\begin{array}{l}\text { Include } \\
\text { continent } \\
\text { dummies }\end{array}$ & $\begin{array}{l}\text { Robust } \\
\text { regression } \\
\text { (for pres- } \\
\text { ence of } \\
\text { outliers) }\end{array}$ & $\begin{array}{l}\text { Include } \\
\text { settler } \\
\text { mortality }\end{array}$ & $\begin{array}{l}\text { Include } \\
\text { colonial } \\
\text { origin } \\
\text { dummies }\end{array}$ & $\begin{array}{l}\text { Using } \\
\text { PRES- } \\
\text { ENCE of } \\
\text { State }\end{array}$ & $\begin{array}{l}\text { Using } \\
\text { AUTON- } \\
\text { OMY of } \\
\text { State }\end{array}$ & $\begin{array}{l}\text { Using } \\
\text { COVER- } \\
\text { AGE of } \\
\text { State }\end{array}$ \\
\hline State & $\begin{array}{l}16.93^{*} \\
(1.79)\end{array}$ & $\begin{array}{l}9.74^{* *} \\
(3.83)\end{array}$ & $\begin{array}{l}15.64^{*} \\
(1.84)\end{array}$ & $\begin{array}{l}14.82 \\
(1.46)\end{array}$ & $\begin{array}{l}7.34 \\
(1.05)\end{array}$ & $\begin{array}{l}8.95^{* *} \\
(3.29)\end{array}$ & $\begin{array}{l}8.65^{* *} \\
(3.19)\end{array}$ & $\begin{array}{l}14.75^{* *} \\
(4.39)\end{array}$ \\
\hline Common Law LO & $\begin{array}{l}6.54 \\
(1.56)\end{array}$ & $\begin{array}{l}2.48 \\
(0.66)\end{array}$ & $\begin{array}{l}6.31 \\
(1.27)\end{array}$ & $\begin{array}{l}6.07 \\
(1.31)\end{array}$ & $\begin{array}{l}-4.57 \\
(-1.05)\end{array}$ & $\begin{array}{l}6.19 \\
(1.09)\end{array}$ & $\begin{array}{l}5.70 \\
(1.15)\end{array}$ & $\begin{array}{l}7.27 \\
(1.28)\end{array}$ \\
\hline Mixed Law LO & & $\begin{array}{l}1.80 \\
(0.43)\end{array}$ & $\begin{array}{l}4.93 \\
(0.76)\end{array}$ & $\begin{array}{l}4.11 \\
(0.68)\end{array}$ & $\begin{array}{l}-5.93 \\
(-1.27)\end{array}$ & $\begin{array}{l}4.84 \\
(1.25)\end{array}$ & $\begin{array}{l}3.77 \\
(0.99)\end{array}$ & $\begin{array}{l}5.74 \\
(1.66)\end{array}$ \\
\hline State x Common Law LO & $\begin{array}{l}-29.18^{* * *} \\
(-2.72)\end{array}$ & $\begin{array}{l}-22.47^{* * *} \\
(-6.36)\end{array}$ & $\begin{array}{l}-28.80^{* *} \\
(-2.34)\end{array}$ & $\begin{array}{l}-22.88^{*} \\
(-1.85)\end{array}$ & $\begin{array}{l}-16.33^{*} \\
(-1.76)\end{array}$ & $\begin{array}{l}-17.61^{*} \\
(-2.56)\end{array}$ & $\begin{array}{l}-20.08^{* *} \\
(-2.89)\end{array}$ & $\begin{array}{l}-23.24^{* *} \\
(-3.26)\end{array}$ \\
\hline State x Mixed Law LO & & $\begin{array}{l}-16.56 \\
(-1.75)\end{array}$ & $\begin{array}{l}-20.31 \\
(-1.30)\end{array}$ & $\begin{array}{l}-22.26^{*} \\
(-1.95)\end{array}$ & $\begin{array}{l}-10.27 \\
(-0.83)\end{array}$ & $\begin{array}{l}-12.30 \\
(-1.47)\end{array}$ & $\begin{array}{l}-13.99 \\
(-1.69)\end{array}$ & $\begin{array}{l}-16.13 \\
(-1.68)\end{array}$ \\
\hline Settler mortality & & & & $\begin{array}{l}-0.01^{* *} \\
(-2.29)\end{array}$ & & & & \\
\hline $\begin{array}{l}\text { Colonial origins ( } F \\
\text { stat) }\end{array}$ & & & & & $\begin{array}{l}8.03^{* * *} \\
{[p=0.000]}\end{array}$ & & & \\
\hline R-squared & 0.176 & 0.323 & 0.144 & 0.264 & 0.426 & 0.122 & 0.123 & 0.149 \\
\hline Observations & 75 & 75 & 75 & 51 & 75 & 75 & 75 & 75 \\
\hline Geographic controls & YES & YES & YES & YES & YES & YES & YES & YES \\
\hline
\end{tabular}

Notes: Robust standard errors are used and $t$-statistics are reported in the parentheses. ${ }^{*},{ }^{* *}$ and $* * *$ indicate significance at the $10 \%, 5 \%$ and $1 \%$ levels, respectively. The intercept estimate is not shown. The omitted legal origin group is "other legal origins", which includes 39 French and 3 German civil law countries. The geographic controls included are latitude, landlockedness, mean elevation, distance to the nearest coast or river, and precipitation. The continent dummies are Asia, Africa, America and Europe (Oceania is the excluded group). Due to the unavailability of data, Barbados, Grenada, and Seychelles are excluded from all columns. Column (4) also excludes another 24 countries, including Armenia, Azerbaijan, Botswana, Cambodia, Cape Verde, Cyprus, Georgia, Israel, Jordan, Kazakhstan, Kyrgyzstan, Lesotho, Malawi, Mongolia, Mozambique, Philippines, Sao Tome and Principe, Swaziland, Syria, Tajikistan, Turkmenistan, Uzbekistan, Zambia and Zimbabwe. 
Table 6: Addressing endogeneity issues

\begin{tabular}{|c|c|c|c|c|}
\hline & (1) & (2) & (3) & (4) \\
\hline & $1^{\text {st }}$-stage $\quad$ regres- & $1^{s t}$-stage regression & $1^{\text {st }}$-stage regression & $2^{n d}$-stage regres- \\
\hline & $\begin{array}{l}\text { sion } \\
\text { (Dep. Var. }= \\
\text { State) }\end{array}$ & $\begin{array}{l}\text { (Dep. } \quad \text { Var. }= \\
\text { State } \text { Common Law LO) }\end{array}$ & $\begin{array}{l}\text { (Dep. } \quad \text { Var. }= \\
\text { State } \\
\text { Mixed Law LO) }\end{array}$ & $\begin{array}{l}\text { sion } \\
\text { (Dep. Var. }= \\
\left.C C^{\text {policy }}\right)\end{array}$ \\
\hline Common Law LO & $\begin{array}{l}-0.215^{* *} \\
(-2.577)\end{array}$ & $\begin{array}{l}-0.056 \\
(-1.142)\end{array}$ & $\begin{array}{l}-0.000 \\
(-0.021)\end{array}$ & $\begin{array}{l}13.874 \\
(1.513)\end{array}$ \\
\hline Mixed Law LO & $\begin{array}{l}-0.016 \\
(-0.156)\end{array}$ & $\begin{array}{l}0.014 \\
(0.733)\end{array}$ & $\begin{array}{l}0.059 \\
(0.759)\end{array}$ & $\begin{array}{l}9.694 \\
(1.233)\end{array}$ \\
\hline Agr.transition & $\begin{array}{l}0.045^{* *} \\
(2.238)\end{array}$ & $\begin{array}{l}0.002 \\
(0.425)\end{array}$ & $\begin{array}{l}0.001 \\
(0.075)\end{array}$ & \\
\hline Agr.transition $\mathrm{x}$ Common Law LO & $\begin{array}{l}0.041^{* *} \\
(2.314)\end{array}$ & $\begin{array}{l}0.095^{* * *} \\
(12.936)\end{array}$ & $\begin{array}{l}0.000 \\
(0.019)\end{array}$ & \\
\hline Agr. transition $\mathrm{x}$ Mixed Law LO & $\begin{array}{l}-0.021 \\
(-1.137)\end{array}$ & $\begin{array}{l}-0.002 \\
(-0.786)\end{array}$ & $\begin{array}{l}0.050^{* * *} \\
(6.046)\end{array}$ & \\
\hline State & & & & $\begin{array}{l}39.300 \\
(1.380)\end{array}$ \\
\hline State x Common Law LO & & & & $\begin{array}{l}-50.394^{* *} \\
(-2.107)\end{array}$ \\
\hline State x Mixed Law LO & & & & $\begin{array}{l}-30.112 \\
(-1.261)\end{array}$ \\
\hline $\begin{array}{l}1^{\text {st }} \text {-stage F-statistic for excluded } \\
\text { instrument }\end{array}$ & 19.16 & 55.88 & 12.98 & - \\
\hline Shea's partial R-squared & 0.114 & 0.263 & 0.455 & - \\
\hline Anderson-Rubin Wald test & - & - & - & $\begin{array}{l}10.65 \\
{[p \quad=0.013]}\end{array}$ \\
\hline $\begin{array}{l}\text { Fractionally resampled Anderson- } \\
\text { Rubin test }\end{array}$ & & & & {$\left[\begin{array}{l}6.861 \\
{[p=0.147]}\end{array}\right.$} \\
\hline R-squared & 0.500 & 0.777 & 0.749 & 0.017 \\
\hline No. of obs. & 73 & 73 & 73 & 73 \\
\hline Geographic controls & YES & YES & YES & YES \\
\hline
\end{tabular}

Notes: Robust standard errors are used and $t$-statistics are reported in the parentheses. $*, * *$ and $* * *$ indicate significance at the $10 \%, 5 \%$ and $1 \%$ levels, respectively. The intercept estimate is not shown. The omitted legal origin group is "other legal origins", which includes 39 French and 3 German civil law countries. The geographic controls included are latitude, landlockedness, mean elevation, distance to the nearest coast or river, and precipitation. The estimations exclude Barbados, Grenada, Fiji, Sao Tome \& Principe and Seychelles. 
Table 7: Additional environmental policy outcomes

\begin{tabular}{|c|c|c|c|c|}
\hline & $(1)$ & $(2)$ & $(3)$ & $(4)$ \\
\hline Dep. Var. is: & $C C C I$ & $\begin{array}{l}\text { Max. lead content } \\
\text { (inversed) }\end{array}$ & $\begin{array}{l}\text { Environmental } \\
\text { Performance Index }\end{array}$ & $\begin{array}{l}\text { Environmental reg- } \\
\text { ulation in agricul- } \\
\text { ture }\end{array}$ \\
\hline State & $\begin{array}{l}1.514 \\
(1.344)\end{array}$ & $\begin{array}{l}0.22 \\
(0.81)\end{array}$ & $\begin{array}{l}1.77 \\
(0.41)\end{array}$ & $\begin{array}{l}10.98 \\
(0.21)\end{array}$ \\
\hline Common Law LO & $\begin{array}{l}0.537 \\
(1.046)\end{array}$ & $\begin{array}{l}0.39^{* *} \\
(2.57)\end{array}$ & $\begin{array}{l}8.46^{* * *} \\
(2.78)\end{array}$ & $\begin{array}{l}69.73^{* * *} \\
(3.04)\end{array}$ \\
\hline Mixed Law LO & $\begin{array}{l}0.249 \\
(0.483)\end{array}$ & $\begin{array}{l}0.39^{* * *} \\
(2.82)\end{array}$ & $\begin{array}{l}0.23 \\
(0.03)\end{array}$ & $\begin{array}{l}60.62^{* * *} \\
(3.86)\end{array}$ \\
\hline State x Common Law LO & $\begin{array}{l}-3.346^{* * *} \\
(-2.665)\end{array}$ & $\begin{array}{l}-0.56^{*} \\
(-1.71)\end{array}$ & $\begin{array}{l}-21.67^{* * *} \\
(-2.95)\end{array}$ & $\begin{array}{l}-89.50^{*} \\
(-1.75)\end{array}$ \\
\hline State x Mixed Law LO & $\begin{array}{l}-1.174 \\
(-0.840)\end{array}$ & $\begin{array}{l}0.01 \\
(0.02)\end{array}$ & $\begin{array}{l}7.16 \\
(0.57)\end{array}$ & $\begin{array}{l}-151.59^{* * *} \\
(-3.15)\end{array}$ \\
\hline R-squared & 0.124 & 0.469 & 0.478 & 0.548 \\
\hline No. of obs. & 74 & 43 & 52 & 26 \\
\hline Geographic controls & YES & YES & YES & YES \\
\hline
\end{tabular}

Notes: The alternative dependent variables are measured on different scales and hence sizes of the estimates are not directly comparable with earlier results or across table columns. Robust standard errors are used and $t$-statistics are reported in the parentheses. $*, * *$ and $* * *$ indicate significance at the $10 \%, 5 \%$ and $1 \%$ levels, respectively. The intercept estimate is not shown. The omitted legal origin group is "Other legal origins", which includes 39 French and 3 German civil law countries. The geographic controls included are latitude, landlockedness, mean elevation, distance to the nearest coast or river, and precipitation. 
Figure 1: Distribution of State (1 - 1800 AD) across the world

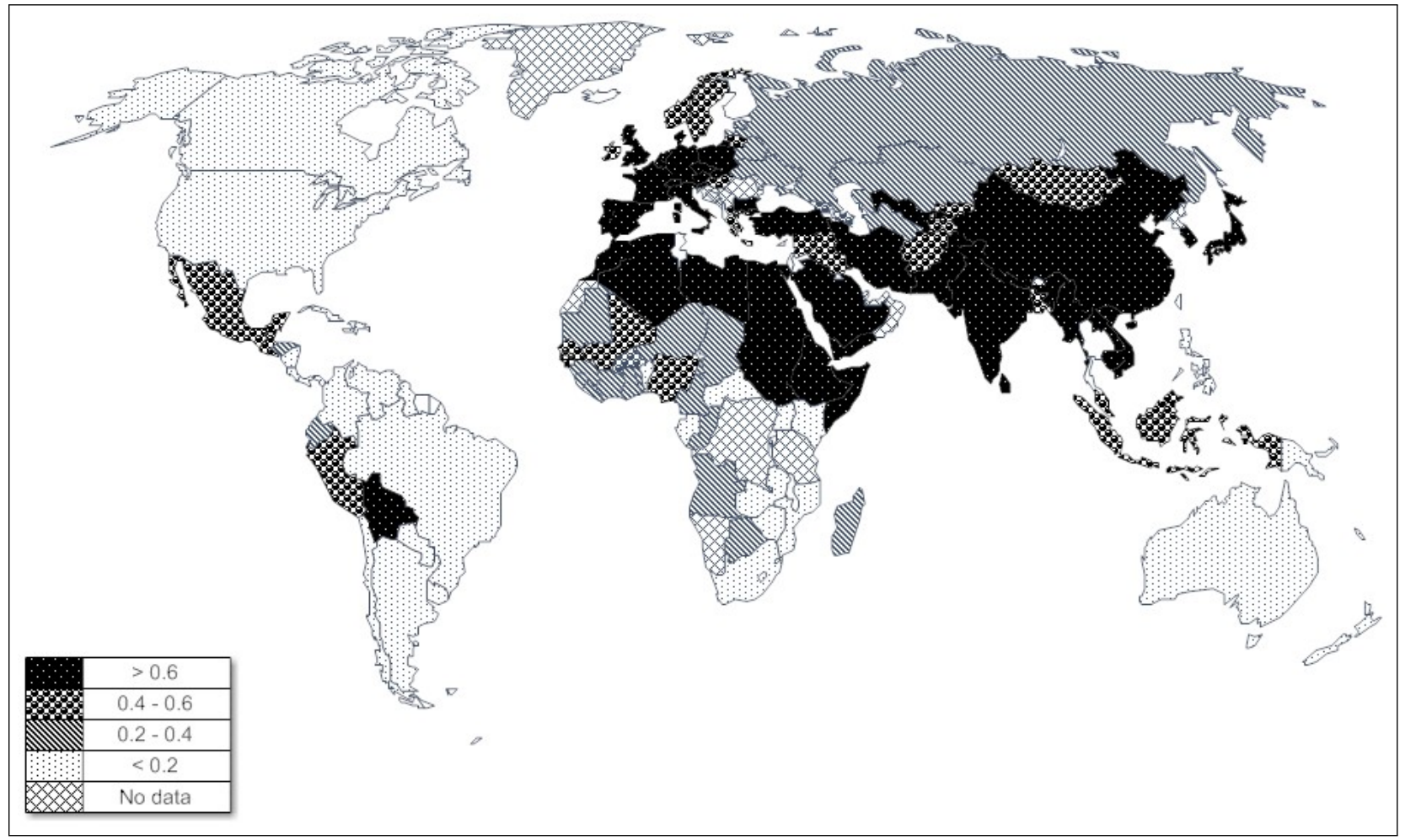


Figure 2: The correlation between Climate Change Policy Index $\left(C C^{\text {policy }}\right)$ and Statehood Experience (State)

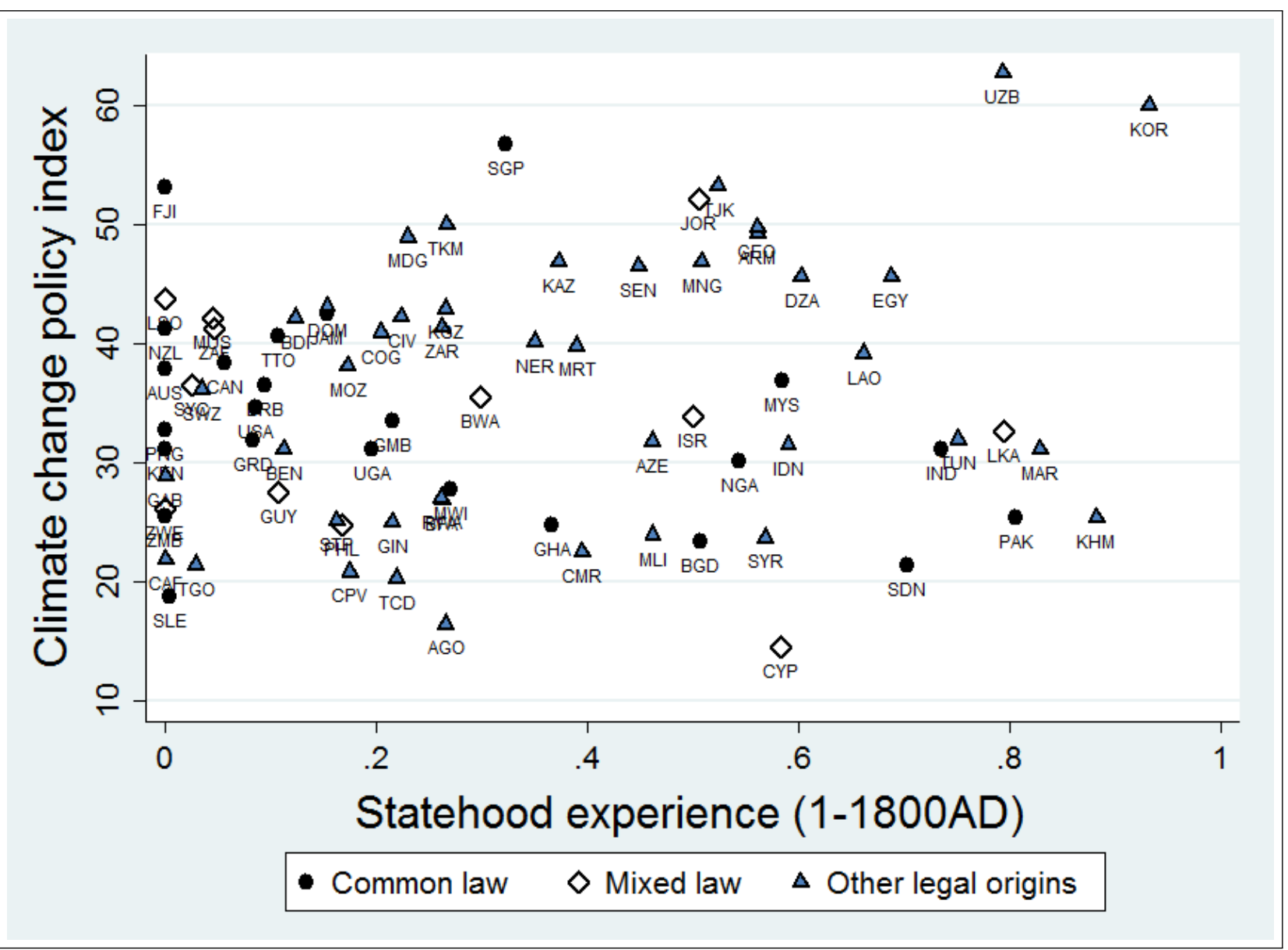

Notes: The scatter plots include 78 countries used in the baseline estimations. "Other" legal origins include French (39 countries) and German civil law countries (3 countries). 
Figure 3: The relationships between Climate Change Policy Index and Statehood Experience across different legal traditions

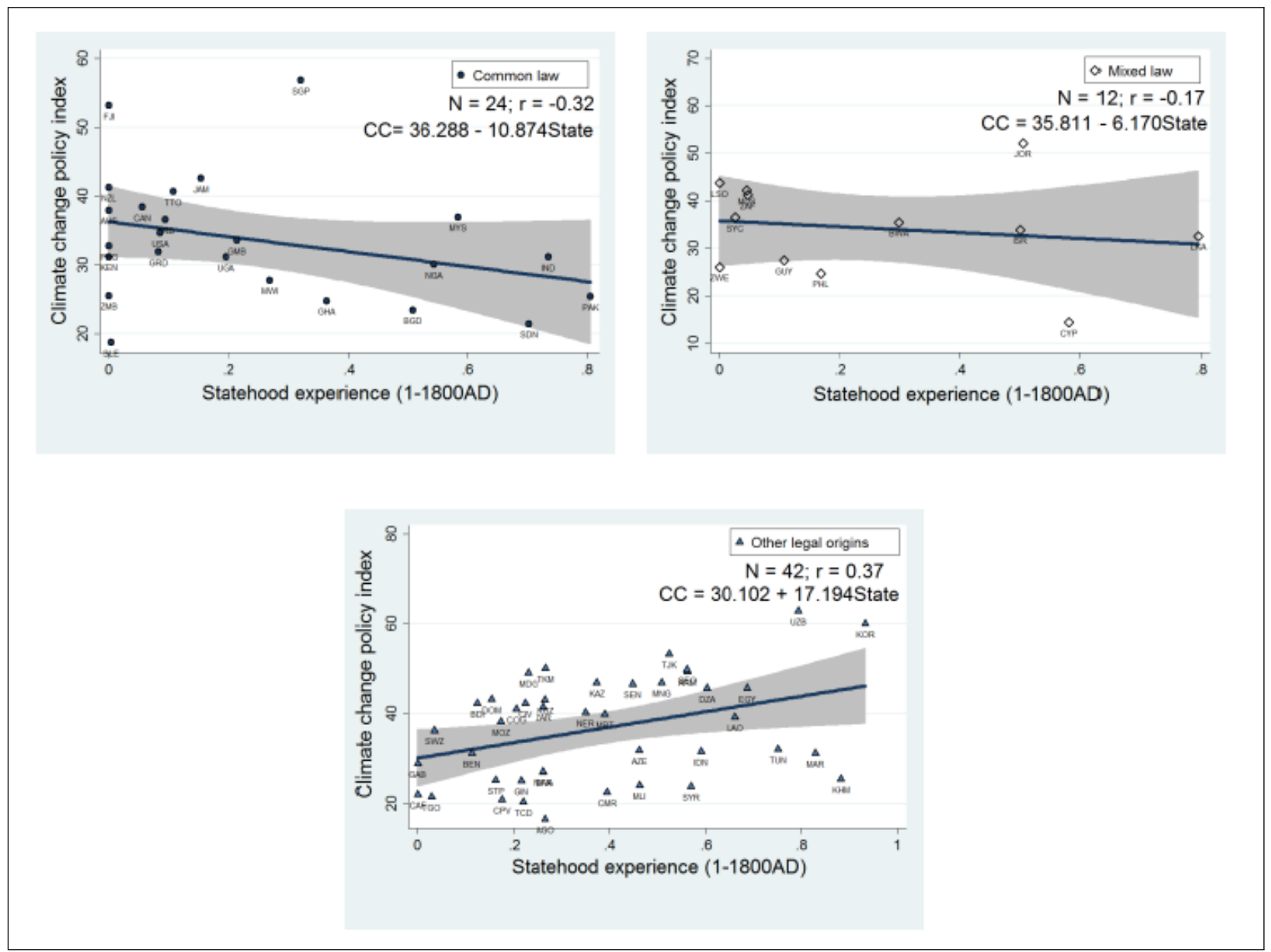

Notes: "Other legal origins" includes the French and German civil law countries. $N$ is the number of countries whereas $r$ is the correlation coefficient between $C C^{\text {policy }}$ and State in each type of legal tradition grouping. A 95 percent confidence interval band is used. 
Figure 4: Partial effect of State $x$ Common Law LO

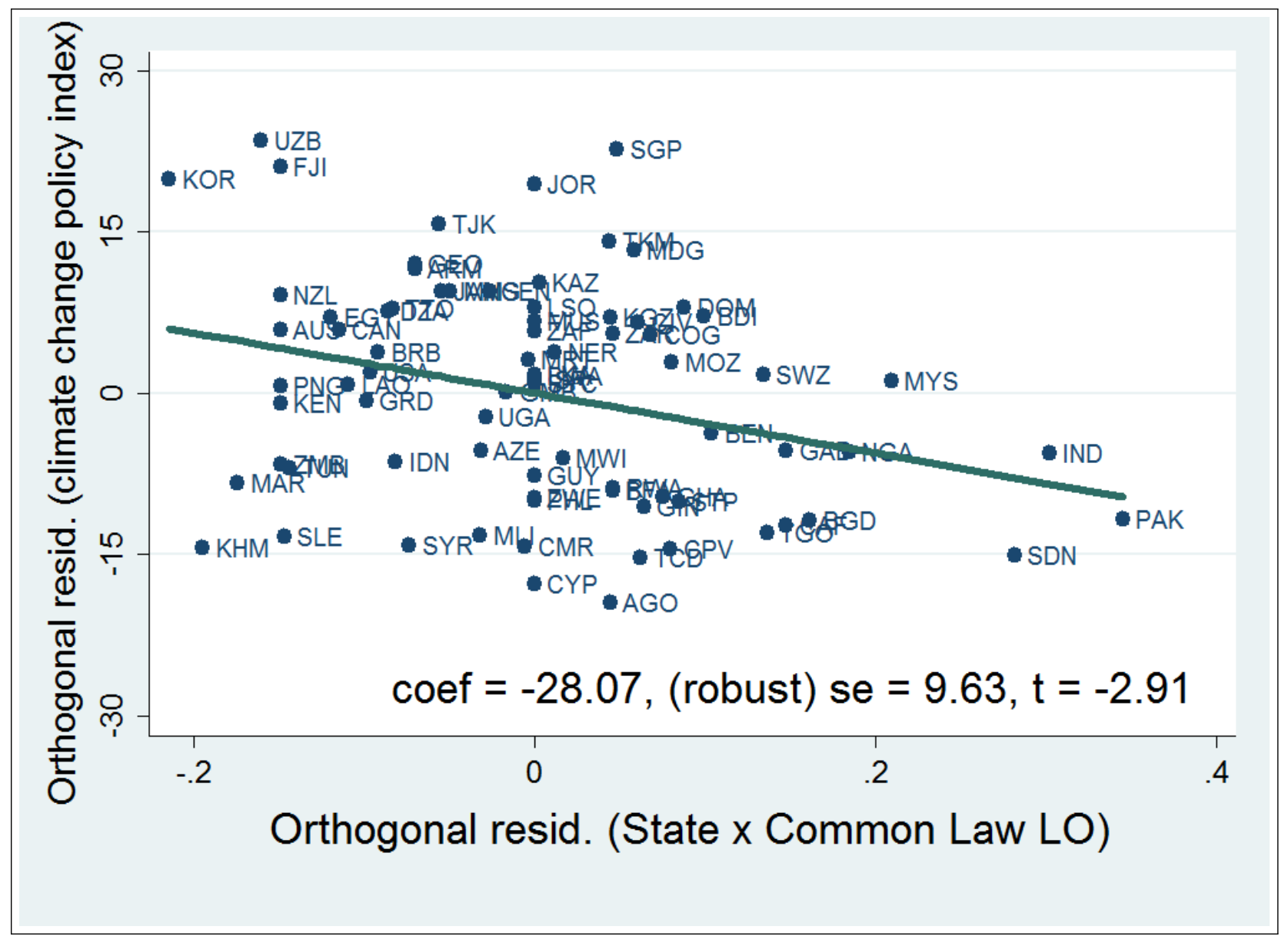

Notes: The scatter plot in the above diagram illustrates the influence of State x Common Law LO on our climate change policy index while partialing out the effects of all other variables included in Eq. (1). This partial regression is based on the regression in column (3) in Table 2. 


\section{Appendix 1: Data}

Table A1: Definition of variables and data sources

\begin{tabular}{ll}
\hline Variable & Description \\
\hline CC & [A.] Main variables \\
& A composite index capturing several key components of \\
& climate change policy, including the ratification of the \\
& United Nations Framework Convention on Climate Change \\
& (UNFCCC) and the Kyoto Protocol, the submission of \\
& national climate report, and financial contributions to the \\
& UNFCCC secretariat. The index also considers whether \\
& these activities were accomplished in a timely manner. \\
& An index of state history covering the period from 1 AD to \\
& 1800 AD, scaled to take values between 0 and 1. The latest \\
version, v3.1, is used. In the robustness checks, two & alternative periods, 1-1500 AD and 1-1650 AD, are used.
\end{tabular}

Common Law LO A dummy variable that identifies the legal tradition of the Civil Law LO company law or commercial code of each country as British Mixed Law LO common law, French civil law, German civil law or Mixed law. An alternative classification that excludes the "Mixed" category, by La Porta et al. (2008), is used in the robustness checks.

Source

Bernauer and Böhmelt (2013) [B.] Control variables

Manufacturing $(\%$
GDP)
Manufacturing value added as a percentage of GDP (averaged over the period 1996-2008).

World Development Indicators (2015)

Income per capita Logged GDP per capita converted to constant 2005 international dollars using PPP rates (averaged over the period 1996-2008).

Democratic capital

A measures of a country's discounted stock of democracy from 1800 to 2010 .

Control of

corruption

Political stability

\section{Latitude}

Ethnolinguistic fractionalization

Landlockedness

Distance to coast

Elevation

Precipitation

Years since agricultural transition

Colonial origins
An index reflecting perceptions of the extent to which state power is used to obtain private gains (averaged over the period 1996-2008).

An index reflecting perceptions of the likelihood that the government will be destabilized or toppled (averaged over the period 1996-2008).

Value of the latitude of each country.

An index capturing the probability that two randomly selected individuals from a country's population would belong to different ethnic groups. The primary source used by Alesina et. al. (2003) is Encyclopedia Britannica (2000). The dates are generally from the early to mid-1990s (the range is 1979-2001, and the median year is 1994).

A dummy variable that equals 1 if a country is fully enclosed by land and 0 otherwise.

The mean distance of a country to the nearest coastline or sea-navigable river (in $\mathrm{km}$ )

The mean elevation of a country above sea level (in $\mathrm{km}$ ).

The average monthly precipitation of a country over the period 1961-1990 (in mm).

The number of years elapsed, in $2000 \mathrm{AD}$, since the transition to agriculture was estimated to occur (in thousand years).

A dummy variable that identifies the colonial origin of a country as Spanish, British, French, Portuguese or other European.
World Development Indicators (2015)

Fredriksson and Neumayer (2013)

Worldwide Governance Indicators (2015)

Worldwide Governance Indicators (2015)

CIA (2015)

Alesina et al. (2003)

CIA (2015)

Gallup et al. (2010)

G-Econ (2008)

G-Econ (2008)

Putterman (2006)

Nunn and Puga (2012) 


\begin{tabular}{|c|c|c|}
\hline $\begin{array}{l}\text { Settler mortality } \\
\text { rate }\end{array}$ & $\begin{array}{l}\text { European settler mortality rates in the 19th century. } \\
\text { Revised estimates of Albouy (2012) are also used as a check. }\end{array}$ & $\begin{array}{l}\text { Acemoglu et al. (2001); } \\
\text { Albouy (2012) }\end{array}$ \\
\hline & [C.] Other outcome variables & \\
\hline$C C C I$ & $\begin{array}{l}\text { The aggregate climate change cooperation index of Bernauer } \\
\text { and Böhmelt (2013). It combines CC } C^{\text {policy (our baseline }} \\
\text { measure of climate change policy) with data on the emission } \\
\text { level and trend. }\end{array}$ & $\begin{array}{l}\text { Bernauer and Böhmelt } \\
(2013)\end{array}$ \\
\hline $\begin{array}{l}\text { Maximum lead } \\
\text { content }\end{array}$ & $\begin{array}{l}\text { The maximum lead content of lease gasoline in } 1996 \text { (gram } \\
\text { per litre) permitted. The data are rescaled so that a higher } \\
\text { value indicates more environmental protection. }\end{array}$ & Lovei (1998) \\
\hline $\begin{array}{l}\text { Environmental } \\
\text { performance index }\end{array}$ & $\begin{array}{l}\text { An environmental performance index for year 2012. Its } \\
\text { computation covers the following nine policy dimensions: } \\
\text { health impacts, air quality, water and sanitation, water } \\
\text { resources, agriculture, forests, fisheries, biodiversity and } \\
\text { habitat, and climate and energy. }\end{array}$ & Hsu et al. (2014) \\
\hline $\begin{array}{l}\text { Environmental } \\
\text { regulation in } \\
\text { agriculture }\end{array}$ & $\begin{array}{l}\text { An index measuring the stringency of environmental } \\
\text { regulation in agriculture in year 1990. Covers water } \\
\text { pollution, air pollution, land use, and biodiversity. }\end{array}$ & $\begin{array}{l}\text { Eliste and Fredriksson } \\
(2002)\end{array}$ \\
\hline
\end{tabular}

Table A2: List of countries included in the estimations (by legal origin)

\begin{tabular}{|c|c|c|c|c|c|}
\hline Common Law LO & $(\operatorname{avg}=0.243)$ & Armenia & 0.561 & Senegal & 0.448 \\
\hline Australia & 0.000 & Azerbaijan & 0.462 & Swaziland & 0.035 \\
\hline Bangladesh & 0.507 & Benin & 0.112 & Syria & 0.569 \\
\hline Barbados & 0.094 & Burkina Faso & 0.262 & Tajikistan & 0.524 \\
\hline Canada & 0.056 & Burundi & 0.123 & Togo & 0.029 \\
\hline Fiji & 0.000 & Cambodia & 0.882 & Tunisia & 0.751 \\
\hline Gambia & 0.216 & Cameroon & 0.395 & Turkmenistan & 0.267 \\
\hline Ghana & 0.366 & Cape Verde & 0.175 & Uzbekistan & 0.794 \\
\hline Grenada & 0.082 & Central African Republic & 0.000 & & \\
\hline India & 0.736 & Chad & 0.219 & Mixed Law LO & $(\operatorname{avg}=0.256)$ \\
\hline Jamaica & 0.153 & Congo, Dem. Rep. & 0.262 & $\overline{\text { Botswana }}$ & 0.299 \\
\hline Kenya & 0.000 & Congo, Rep. & 0.205 & Cyprus & 0.583 \\
\hline Malawi & 0.270 & Cote d'Ivoire & 0.223 & Guyana & 0.107 \\
\hline Malaysia & 0.585 & Dominican Republic & 0.153 & Israel & 0.501 \\
\hline New Zealand & 0.000 & Egypt & 0.688 & Jordan & 0.505 \\
\hline Nigeria & 0.544 & Gabon & 0.000 & Lesotho & 0.000 \\
\hline Pakistan & 0.806 & Guinea & 0.215 & Mauritius & 0.045 \\
\hline Papua New Guinea & 0.000 & Indonesia & 0.590 & Philippines & 0.168 \\
\hline Sierra Leone & 0.003 & Kazakhstan & 0.373 & Seychelles & 0.025 \\
\hline Singapore & 0.322 & Kyrgyzstan & 0.265 & South Africa & 0.046 \\
\hline Sudan & 0.703 & Laos & 0.662 & Sri Lanka & 0.795 \\
\hline Trinidad and Tobago & 0.107 & Madagascar & 0.230 & Zimbabwe & 0.000 \\
\hline Uganda & 0.196 & Mali & 0.462 & & \\
\hline United States & 0.086 & Mauritania & 0.390 & \multicolumn{2}{|c|}{ German Civil Law LO (avg $=0.667)$} \\
\hline \multirow[t]{2}{*}{ Zambia } & 0.000 & Morocco & 0.829 & Georgia & 0.561 \\
\hline & & Mozambique & 0.173 & Korea, Rep. & 0.933 \\
\hline French Civil Law LO & $(\operatorname{avg}=0.358)$ & Niger & 0.350 & Mongolia & 0.508 \\
\hline Algeria & 0.603 & Rwanda & 0.262 & & \\
\hline Angola & 0.266 & Sao Tome and Principe & 0.162 & & \\
\hline
\end{tabular}

Notes: The estimations include up to 78 countries listed in the table above. Figures in the table indicate statehood experience accumulated over the period 1-1800 AD. 


\section{Appendix 2: Construction of State History variable (State)}

The state history index of Putterman (2004) includes 39 periods of 50 years spanning from 1 to $1950 \mathrm{AD}$. In our study, we restrict the period to 1-1800 AD (i.e., 36 periods). The index is made up of the following three components:

$\begin{array}{ll}S T^{\text {PRESENCE }:} & \text { Is there a government above the tribal level? } \\ & {[Y \text { YeS }=1 ; \text { No }=0]}\end{array}$

$S T^{\text {AUTONOMY }}$ Is this government foreign or locally based?

$[$ Local $=1 ;$ In between $=0.75 ;$ Foreign $=0.5]$

ST COVERAGE $:$ How much of the territory of the modern country was ruled by this government? $[\dot{i} 50 \%=1 ; 25-50 \%=0.75 ; 10-25 \%=0.5 ; ¡ 10 \%=0.3]$

The extent of state presence $\left(S A_{t}\right)$ in any particular 50 years period $(t)$ is measured as the product of the scores on these components and 50. Consequently, a score of 0 indicates no presence of state, 25 reflects that a country has a supra-tribal authority but its entire territory is ruled by a foreign authority, and 50 indicates the presence of an autonomous nation, and so on.

$$
\begin{gathered}
S A_{t}=S T^{\text {PRESENCE }} \times S T^{\text {AUTONOMY }} \times S T^{\text {COVERAGE }} \times 50 \\
0 \leq S A_{t} \leq 50, t=1,2, \ldots, 36
\end{gathered}
$$

The length of state history, or state antiquity (State), is measured as the cumulative presence of state by combining data over the entire 36 periods. A 5 percent discount rate is applied to allow for the fact that states formed in the more distant past have relatively less influence on today's economic conditions. To ease interpretation, the series is scaled into 0 and 1 using its maximum possible value. Accordingly, state history for a particular country over 18 centuries $(1-1800 \mathrm{AD})$ is calculated as follows:

$$
\text { State }=\frac{\sum_{t=1}^{36}(1.05)^{1-t} \cdot S A_{t}}{\sum_{t=1}^{36}(1.05)^{1-t} \cdot 50} ; \quad 0 \leq \text { State } \leq 1
$$

\begin{tabular}{|c|c|c|c|c|c|}
\hline & $\begin{array}{l}\text { PRESENCE } \\
\text { of State }\end{array}$ & $\begin{array}{c}\text { AUTONOMY } \\
\text { of State }\end{array}$ & $\begin{array}{c}\text { COVERAGE } \\
\text { of State }\end{array}$ & State & No. of countries \\
\hline Africa & 0.419 & 0.371 & 0.332 & 0.282 & 46 \\
\hline Asia & 0.866 & 0.688 & 0.786 & 0.619 & 37 \\
\hline America & 0.364 & 0.233 & 0.325 & 0.193 & 27 \\
\hline Europe & 0.829 & 0.609 & 0.770 & 0.551 & 37 \\
\hline Oceania & 0.000 & 0.000 & 0.000 & 0.000 & 4 \\
\hline All countries & 0.608 & 0.473 & 0.541 & 0.407 & 151 \\
\hline
\end{tabular}

Table A3: Average values of State with sub-indices across continents

Notes: PRESENCE of State is measured as: $\left(\sum_{t=1}^{36}(1.05)^{1-t} \cdot S T^{\text {PRESENCE }} t \cdot 50\right) /\left(\sum_{t=1}^{36}(1.05)^{1-t} \cdot 50\right)$ and so on. ST PRESENCE captures the presence of a government above the tribal level; $S T^{\text {AUTONOMY }}$ reflects whether this government is foreign or locally based; and $S T^{\text {COVERAGE }}$ measures the proportion of the current territory covered by this government. State is given as: $\left(\sum_{t=1}^{36}(1.05)^{1-t} \cdot S A_{t}\right) /\left(\sum_{t=1}^{36}(1.05)^{1-t} \cdot 50\right)$, where $S A_{t}=S^{\text {PRESENCE }} x$ ST $^{\text {AUTONOMY }} x S T^{\text {COVERAGE }} x 50 . \quad$ Data for all countries available are shown.

The distribution of State and its components for all available 151 countries is given in Table A3. In general, states in Asia and Europe are at least twice as old as those in Africa and America. Cambodia, China, Ethiopia, Japan, South Korea, Morocco, Myanmar, Nepal and Turkey were among the nations with the highest levels of state experience (average State $=0.883$ ) by 1800 AD. Countries in Oceania, 
including Australia, New Zealand, Fiji and Papua New Guinea had zero state values as of 1800 AD. African nations such as Central African Republic, Gabon, Kenya, Lesotho, Liberia, Seychelles, Sierra Leone, Togo, Zambia and Zimbabwe (average State $=0.006$ ) are among those countries that have the youngest states, many of which also had no state experience at that time. It is interesting to observe that the emergence of states in several sub-Saharan African countries, such as the Central African Republic, Gabon, Kenya and Zimbabwe, was in fact the outcome of the 19th century colonization by the Western powers, either the British or the French, without which these nations may not have existed.

Tables A4 and A5 illustrate how the state history index is constructed for older and younger states, respectively, in each continent by giving a country example for each continent. Although our measure covers only 1-1800AD, for completeness we provide information for all time periods available (11950AD). The relatively experienced states considered are Egypt (Africa), China (Asia), Peru (America), France (Europe) and Australia (Oceania) whereas the relatively inexperienced states are Kenya (Africa), the Philippines (Asia), Uruguay (America), Latvia (Europe) and Papua New Guinea (Oceania). 
Table A4: Examples of state history construction for experienced states in each continent

\begin{tabular}{|c|c|c|c|c|c|}
\hline Region & AFRICA & ASIA & AMERICA & EUROPE & OCEANIA \\
\hline Country & Egypt & China & Peru & France & Australia \\
\hline 1-50 AD & \multirow{15}{*}{$\begin{array}{c}1,0.5,1 \\
\text { (under Roman's } \\
\text { occupation) }\end{array}$} & \multirow{3}{*}{$\begin{array}{c}1,1,1 \\
\text { (ruled by the } \\
\text { Han dynasty) }\end{array}$} & \multirow{10}{*}{$\begin{array}{c}0,0,0 \\
\text { (non-existence of } \\
\text { states) }\end{array}$} & \multirow{8}{*}{$\begin{array}{l}1,0.5,1 \\
\text { (Gaul was under } \\
\text { the Roman's rule) }\end{array}$} & \\
\hline $\begin{array}{c}51-100 \mathrm{AD} \\
101-150 \mathrm{AD}\end{array}$ & & & & & \\
\hline $151-200 \mathrm{AD}$ & & & & & \\
\hline $201-250 \mathrm{AD}$ & & \multirow{7}{*}{$\begin{array}{l}1,1,0.75 \\
\text { (the Han empire } \\
\text { was split into } \\
\text { several warring } \\
\text { states) }\end{array}$} & & & \\
\hline $251-300 \mathrm{AD}$ & & & & & \\
\hline $301-350 \mathrm{AD}$ & & & & & \\
\hline 351-400 AD & & & & & \\
\hline$\frac{401-450 \mathrm{AD}}{451-500 \mathrm{AD}}$ & & & & & \\
\hline $501-550 \mathrm{AD}$ & & & & \multirow{5}{*}{$\begin{array}{c}1,1,0.75 \\
\text { (controlled by } \\
\text { multiple } \\
\text { Germanic } \\
\text { kingdoms) }\end{array}$} & \\
\hline 551-600 AD & & & & & \\
\hline $601-650$ AD & & \multirow{3}{*}{$\begin{array}{c}1,1,1 \\
\text { (unified under } \\
\text { the Sui and, later, } \\
\text { the T'ang } \\
\text { dynasties) }\end{array}$} & \multirow{2}{*}{$\begin{array}{c}1,1,0.5 \\
\text { (the Huari state } \\
\text { existed in the } \\
\text { southern part) }\end{array}$} & & \\
\hline 651-700 AD & & & & & \\
\hline 701-750 AD & & & \multirow[b]{2}{*}{$\begin{array}{c}1,1,1 \\
\text { (Huari grew to } \\
\text { become an } \\
\text { empire) }\end{array}$} & & \\
\hline $751-800 \mathrm{AD}$ & & $\begin{array}{c}1,1,0.75 \\
\text { (central regime } \\
\text { broke down, } \\
\text { followed by some } \\
\text { political chaos) }\end{array}$ & & $\begin{array}{c}1,1,0.895 \\
\text { (rule was unified } \\
\text { by Charlemagne } \\
\text { in } 771 \text { ) }\end{array}$ & \\
\hline $801-850 \mathrm{AD}$ & & \multirow{2}{*}{$\begin{array}{c}1,1,1 \\
\text { (the T'ang power } \\
\text { was restored) }\end{array}$} & \multirow{12}{*}{$\begin{array}{l}1,1,0.75 \\
\text { (the Huari empire } \\
\text { collapsed and the } \\
\text { area was ruled by } \\
\text { a number of } \\
\text { smaller states) }\end{array}$} & $\begin{array}{c}1,1,1 \\
\text { (under unified } \\
\text { domestic rule) }\end{array}$ & \\
\hline $851-900 \mathrm{AD}$ & $\begin{array}{c}1,1,1 \\
\text { (establishment of } \\
\text { the Tulunid } \\
\text { dynasty) }\end{array}$ & & & \multirow{8}{*}{$\begin{array}{c}1,1,0.75 \\
\text { (rule was divided } \\
\text { among several } \\
\text { Frankish } \\
\text { kingdoms) }\end{array}$} & \\
\hline 901-950 AD & $\begin{array}{c}1,0.5,1 \\
\text { (became a foreign- } \\
\text { based caliphal } \\
\text { province) }\end{array}$ & \multirow{2}{*}{$\begin{array}{c}1,1,0.75 \\
\text { (centralized order } \\
\text { collapsed again } \\
\text { and multiple } \\
\text { kingdoms } \\
\text { emerged) }\end{array}$} & & & $\begin{array}{c}0,0,0 \\
\text { (non-existence of } \\
\text { states) }\end{array}$ \\
\hline 951-1000 AD & $\begin{array}{l}1,0.77,1 \\
\text { (the Fatimid } \\
\text { Caliphate was } \\
\text { established in } \\
973 \text { ) }\end{array}$ & & & & \\
\hline 1001-1050 AD & \multirow{4}{*}{$\begin{array}{c}1,1,1 \\
\text { (under the rule of } \\
\text { the Egypt-based } \\
\text { Fatimids) } \\
1,0.855,1 \\
\text { (the Ayyubid } \\
\text { dynasty became } \\
\text { allegiant to the } \\
\text { foreign-based } \\
\text { Abbasid } \\
\text { Caliphate in } \\
1171 \text { ) } \\
\end{array}$} & \multirow{5}{*}{$\begin{array}{l}1,1,1 \\
\text { (power was united } \\
\text { under the Sung } \\
\text { dynasty) }\end{array}$} & & & \\
\hline $1051-1100 \mathrm{AD}$ & & & & & \\
\hline $1101-1150 \mathrm{AD}$ & & & & & \\
\hline $1151-1200 \mathrm{AD}$ & & & & & \\
\hline $1201-1250 \mathrm{AD}$ & $\begin{array}{c}1,0.75,1 \\
\text { (became quasi- } \\
\text { independent } \\
\text { under the } \\
\text { Ayyubids) } \\
\end{array}$ & & & & \\
\hline $1251-1300 \mathrm{AD}$ & \multirow{3}{*}{$\begin{array}{l}1,1,1 \\
\text { (under the } \\
\text { autonomy of the } \\
\text { Mamluk dynasty) }\end{array}$} & $\begin{array}{c}1,0.895,1 \\
\text { (the Yuan } \\
\text { dynasty was } \\
\text { established in } \\
1279 \text { ) }\end{array}$ & & \multirow{2}{*}{$\begin{array}{l}1,1,1 \\
\text { (under centralized } \\
\text { rule and area } \\
\text { expanded to } \\
\text { nearly its current } \\
\text { size) }\end{array}$} & \\
\hline 1301-1350 AD & & $\begin{array}{c}1,0.75,1 \\
\text { (under the quasi- } \\
\text { local Mongol rule) }\end{array}$ & & & \\
\hline 1351-1400 AD & & $1,0.91,1$ & & $1,0.75,0.75$ & \\
\hline
\end{tabular}




\begin{tabular}{|c|c|c|c|c|c|}
\hline \multirow[b]{2}{*}{$1401-1450 \mathrm{AD}$} & \multirow{4}{*}{$\begin{array}{c} \\
1,0.67,1 \\
\text { (conquered by the } \\
\text { Ottomans in } \\
1517 \text { ) } \\
\end{array}$} & $\begin{array}{c}\text { (the Yuan } \\
\text { dynasty collapsed } \\
\text { and replaced by } \\
\text { the Ming dynasty } \\
\text { in 1368) }\end{array}$ & & \multirow[t]{2}{*}{$\begin{array}{c}\text { (a large part of } \\
\text { the area was held } \\
\text { by the English } \\
\text { during the } \\
\text { Hundred Years } \\
\text { War) }\end{array}$} & \\
\hline & & \multirow{7}{*}{$\begin{array}{c}1,1,1 \\
\text { (the Chinese rule } \\
\text { was integrated } \\
\text { under the Ming } \\
\text { and Ch'ing } \\
\text { dynasties) }\end{array}$} & & & \\
\hline $1451-1500 \mathrm{AD}$ & & & $\begin{array}{c}1,1,1 \\
\text { (the Inca empire } \\
\text { united the entire } \\
\text { area) }\end{array}$ & \multirow{2}{*}{$\begin{array}{l}1,1,1 \\
\text { (the Hundred } \\
\text { Years War ended } \\
\text { and territory was } \\
\text { regained) }\end{array}$} & \\
\hline $1501-1550 \mathrm{AD}$ & & & $\begin{array}{c}1,0.82,1 \\
\text { (conquered by the } \\
\text { Spanish in } 1532 \text { ) }\end{array}$ & & \\
\hline $1551-1600 \mathrm{AD}$ & \multirow{2}{*}{$\begin{array}{c}1,0.5,1 \\
\text { (under the } \\
\text { Ottomans' rule) }\end{array}$} & & \multirow{2}{*}{$\begin{array}{c}1,0.5,1 \\
\text { (under the } \\
\text { Spanish colonial } \\
\text { rule) }\end{array}$} & \multirow{2}{*}{\multicolumn{2}{|c|}{$\begin{array}{c}1,1,0.75 \\
\text { (rule was divided } \\
\text { by domestic } \\
\text { religious wars) } \\
\end{array}$}} \\
\hline $\begin{array}{l}1601-1650 \text { AD } \\
1651-1700 \mathrm{AD} \\
1701-1750 \mathrm{AD} \\
1751-1800 \mathrm{AD}\end{array}$ & & & & & \\
\hline $1801-1850 \mathrm{AD}$ & $\begin{array}{c}1,0.75,1 \\
\text { (allowed partial } \\
\text { autonomy under } \\
\text { the Ottomans and } \\
\text { the French) }\end{array}$ & & $\begin{array}{c}1,0.79,1 \\
\text { (gained } \\
\text { independence in } \\
1821 \text { ) }\end{array}$ & & $\begin{array}{c}1,0.75,1 \\
\text { (British } \\
\text { settlement) }\end{array}$ \\
\hline $1851-1900 \mathrm{AD}$ & $\begin{array}{c}1,0.66,1 \\
\text { (under the British } \\
\text { occupation in } \\
1882 \text { ) }\end{array}$ & & & $\begin{array}{c}1,1,1 \\
\text { (mostly under } \\
\text { unified control) }\end{array}$ & \\
\hline $1901-1950 \mathrm{AD}$ & $\begin{array}{l}1,0.78,1 \\
\text { (independent from } \\
\text { Britain in 1922) }\end{array}$ & $\begin{array}{c}1,1,0.875 \\
\text { (The Ch'ing rule } \\
\text { ceased in } 1911 \\
\text { and was replaced } \\
\text { the Republic of } \\
\text { China, but the } \\
\text { nation was } \\
\text { politically } \\
\text { fragmented) }\end{array}$ & $\begin{array}{c}1,1,1 \\
\text { (under } \\
\text { independent rule) }\end{array}$ & & $\begin{array}{c}1,1,1 \\
\text { (gained } \\
\text { independence } \\
\text { from Great } \\
\text { Britain) }\end{array}$ \\
\hline
\end{tabular}

Notes: The values in each entry reflect $S T^{\text {PRESENCE }}, S T^{\text {AUTONOMY }}$ and $S T^{\text {COVERAGE}}$. For instance, ST ${ }^{\text {PRESENCE }}$ is 1 , $S T^{\text {AUTONOMY }}$ is 0.5 and $S T^{\text {COVERAGE }}$ is 1 for Egypt in every 50-year period from 1 to 850 AD. Source: Putterman (2004). 
Table A5: Examples of state history construction for inexperienced states by continent

\begin{tabular}{|c|c|c|c|c|c|}
\hline Region & AFRICA & ASIA & AMERICA & EUROPE & OCEANIA \\
\hline Country & Kenya & Philippines & Uruguay & Moldova & $\begin{array}{c}\text { Papua New } \\
\text { Guinea }\end{array}$ \\
\hline $1-50 \mathrm{AD}$ & \multirow{36}{*}{$\begin{array}{c}0,0,0 \\
\text { (non-existence } \\
\text { of states) }\end{array}$} & \multirow{28}{*}{$\begin{array}{c}0,0,0 \\
\text { (non-existence of } \\
\text { states) }\end{array}$} & \multirow{32}{*}{$\begin{array}{c}0,0,0 \\
\text { (non-existence of } \\
\text { states) }\end{array}$} & \multirow{17}{*}{$\begin{array}{c}0,0,0 \\
\text { (non-existence } \\
\text { of states) }\end{array}$} & \multirow{36}{*}{$\begin{array}{c}0,0,0 \\
\text { (non-existence of } \\
\text { states) }\end{array}$} \\
\hline $51-100 \mathrm{AD}$ & & & & & \\
\hline 101-150 AD & & & & & \\
\hline 151-200 AD & & & & & \\
\hline $201-250 \mathrm{AD}$ & & & & & \\
\hline $251-300 \mathrm{AD}$ & & & & & \\
\hline $301-350 \mathrm{AD}$ & & & & & \\
\hline$\frac{351-400 \mathrm{AD}}{401-450 \mathrm{AD}}$ & & & & & \\
\hline$\frac{401-450 \mathrm{AD}}{451-500 \mathrm{AD}}$ & & & & & \\
\hline $501-550 \mathrm{AD}$ & & & & & \\
\hline $551-600 \mathrm{AD}$ & & & & & \\
\hline 601-650 AD & & & & & \\
\hline 651-700 AD & & & & & \\
\hline 701-750 AD & & & & & \\
\hline 751-800 AD & & & & & \\
\hline 801-850 AD & & & & & \\
\hline 851-900 AD & & & & & \\
\hline 901-950 AD & & & & \multirow{5}{*}{$\begin{array}{c}1,0.5,1 \\
\text { (ruled by } \\
\text { Kievan Rus) }\end{array}$} & \\
\hline 951-1000 AD & & & & & \\
\hline $\begin{array}{l}1001-1050 \mathrm{AD} \\
1051-1100 \mathrm{AD}\end{array}$ & & & & & \\
\hline $1101-1150 \mathrm{AD}$ & & & & & \\
\hline 1151-1200 AD & & & & & \\
\hline $1201-1250 \mathrm{AD}$ & & & & \multirow{4}{*}{$\begin{array}{c}1,0.5,1 \\
\text { (pledged } \\
\text { allegiance to } \\
\text { the Tartars) }\end{array}$} & \\
\hline 1251-1300 AD & & & & & \\
\hline 1301-1350 AD & & & & & \\
\hline 1351-1400 AD & & & & & \\
\hline $1401-1450 \mathrm{AD}$ & & & & \multirow{3}{*}{$\begin{array}{c}1,0.5,1 \\
\text { (became part } \\
\text { of the } \\
\text { principality of } \\
\text { Moldavia until } \\
1513 \text { ) } \\
\end{array}$} & \\
\hline $1451-1500 \mathrm{AD}$ & & & & & \\
\hline 1501-1550 AD & & $\begin{array}{l}1,1,0.75 \\
\text { (ruled by two local } \\
\text { Islamic sultanates) }\end{array}$ & & & \\
\hline 1551-1600 AD & & $\begin{array}{c}1,0.75,0.75 \\
\text { (partially occupied } \\
\text { by the Spanish) }\end{array}$ & & \multirow{5}{*}{$\begin{array}{l}1,0.5,1 \\
\text { (belonged to } \\
\text { the Ottoman } \\
\text { Empire) }\end{array}$} & \\
\hline $1601-1650 \mathrm{AD}$ & & \multirow{6}{*}{$\begin{array}{l}1,0.5,1 \\
\text { (rule was unified the } \\
\text { Spanish) }\end{array}$} & & & \\
\hline 1651-1700 AD & & & & & \\
\hline $1701-1750 \mathrm{AD}$ & & & \multirow{2}{*}{$\begin{array}{c}1,0.5,1 \\
\text { (occupied by } \\
\text { foreign forces) }\end{array}$} & & \\
\hline 1751-1800 AD & & & & & \\
\hline 1801-1850 AD & & & $\begin{array}{c}1,0.72,1 \\
\text { (independent } \\
\text { since 1828) }\end{array}$ & \multirow{3}{*}{$\begin{array}{c}1,0.5,1 \\
\text { (largely } \\
\text { occupied by } \\
\text { Soviet Union) }\end{array}$} & \\
\hline 1851-1900 AD & & & \multirow[b]{2}{*}{$\begin{array}{c}1,1,1 \\
\text { (under } \\
\text { independent } \\
\text { rule) }\end{array}$} & & \\
\hline 1901-1950 AD & $\begin{array}{l}1,0.5,1 \\
\text { (became a } \\
\text { colony of the } \\
\text { British) }\end{array}$ & $\begin{array}{c}1,0.75,1 \\
\text { (local autonomy } \\
\text { coexisted with } \\
\text { control by the } \\
\text { United States) }\end{array}$ & & & $\begin{array}{l}1,0.5,0.75 \\
\text { (occupied by the } \\
\text { British, Germans, } \\
\text { and Dutch) }\end{array}$ \\
\hline
\end{tabular}

Notes: The values in each entry reflect $S T^{\text {PRESENCE }}, S T^{\text {AUTONOMY }}$ and $S T^{\text {COVERAGE }}$. Source: Putterman (2004). 